\title{
Differential Regulation of Neuronal Sodium Channel Expression by Endogenous and Exogenous Tyrosine Kinase Receptors Expressed in Rat Pheochromocytoma Cells
}

\author{
Gary R. Fanger, ${ }^{1}$ John R. Jones, ${ }^{1}$ and Robert A. Maue ${ }^{1,2}$ \\ Departments of 'Biochemistry and 'Physiology, Dartmouth Medical School, Hanover, New Hampshire 03755-3833
}

The biological activity of growth factors that act through receptor tyrosine kinases (RTKs) can differ dramatically, depending on both the properties of the RTKs and the cellular environment in which the RTKs are expressed. To determine the ability of different RTKs to elicit ras-independent responses central to neuronal differentiation, we analyzed voltage-dependent sodium $(\mathrm{Na})$ channel expression in rat pheochromocytoma ( $\mathrm{PC12}$ ) cells after activation of a variety of endogenously and exogenously expressed RTKs. In PC12 cells expressing trkB (Ip et al., 1993), the increase in $\mathrm{Na}$ current density caused by brain-derived neurotrophic factor (BDNF) was similar to that observed upon activation of endogenous trkA by NGF. BDNF also increased type II Na channel mRNA expression, as did neurotrophin-3 in PC12 cells expressing trkC (Tsoulfas et al., 1993). In contrast, insulin did not increase type II Na channel mRNA expression or $\mathrm{Na}$ current density in PC12 cells, while epidermal growth factor (EGF) elicited small, yet reproducible increases in type II $\mathrm{Na}$ channel mRNA and $\mathrm{Na}$ current density when compared to NGF, even upon coexpression of an EGF receptor/p75 receptor chimera (Yan et al., 1991). Finally, in PC12 cells expressing $\beta$-platelet-derived growth factor (PDGF) receptors (Heasley and Johnson, 1992), PDGF increased type II $\mathrm{Na}$ channel mRNA and $\mathrm{Na}$ current density to the same extent as NGF. The results show the capabilities of these RTKs in eliciting $\mathrm{Na}$ channel expression and the specificity arising due to differences in their intrinsic properties.

IKey words: neuronal differentiation, neurotrophic factors, growth factors, sodium channels, gene expression, patch clamping]

Neuronal survival, growth, and differentiation depends upon a variety of growth factors acting through specific receptor tyrosine kinases (RTKs) (for reviews, see Barde, 1989; Wagner and Kostyk, 1991; Chao, 1992a). Among these factors, NGF has

\footnotetext{
Received Apr. 21, 1994; revised June 3, 1994; accepted June 15, 1994.

We thank G. Yancopoulos for the trkB/PCI 2 cells; D. Kaplan for the 6-24 and 6-15 PC12 sublines; P. Tsoulfas and L. Parada for the RNA samples from the trkC-PCl 2 cells; M. Chao for the EN30B cells; L. Heasley for the PC-PDGFR102. PC-PDGFR-111, and PC-NEO-102 cells; Regeneron Pharmaceuticals for the BDNF; J. Belasco and M. Greenberg for the fos CDNA; M. Kuhne and G. Lienhard for Western blot analysis of PC12 lysates; M. Chao, L. Heasley, L. Henderson, D. Kaplan, and L. Parada for comments on the manuscript; and J. Dunlap for use of his densitometry equipment. This research was supported by grants awarded to R.A.M. by the Alfred P. Sloan Foundation and the National Institutes of Health (NS28767).

Correspondence should be addressed to Dr. Robert A. Maue, Department of Physiology, Dartmouth Medical School, Hanover, NH 03755-3833.

Copyright (c) 1995 Society for Neuroscience $0270-6474 / 95 / 150202-12 \$ 05.00 / 0$
}

been extensively studied (for reviews, see Levi-Montalcini, 1987; Bothwell, 1991; Gage et al., 1991), with the product of the protooncogene trkA, either alone or in conjunction with a $75 \mathrm{kDa}$ membrane spanning protein ( $p 75$ ), serving as its receptor (for discussion, see Chao, 1992a; Meakin and Shooter, 1992). While recent discovery of other members of the trk RTK family, such as trkB and trkC (for review, see Chao, 1992a), as well as other NGF-related neurotrophins, such as brain-derived neurotrophic factor (BDNF) and neurotrophin-3 (NT-3) (for review, see Thoenen, 1991), have emphasized the importance of neurotrophins in neuronal survival and differentiation (for reviews, see Barde, 1989; Gage et al., 1991; Wagner and Kostyk, 1991), other factors also appear to contribute to these processes. For example, epidermal growth factor (EGF) enhances not only neuronal proliferation, but in vitro survival and neurite outgrowth of neocortical neurons (Walicke and Baird, 1988). Furthermore, insulin and its receptor are present in the nervous system, and together can promote neuronal viability, neurite outgrowth, and the differentiation of neuroblastoma cells (Bhat, 1983; RecioPinto et al., 1986; for discussion, see Saltiel and Decker, 1991). Finally, both forms of platelet-derived growth factor (PDGF) and PDGF receptor are expressed throughout the mammalian nervous system (Sasahara et al., 1991; Yeh et al., 1991; Eccleston et al., 1993) and PDGF enhances survival, neurite outgrowth, and differentiation of rat brain neurons in vitro, suggesting a neurotrophic or neuroregulatory role (Smits et al., 1991). Despite evidence suggesting these factors play a role in the nervous system, however, the extent to which they govern cellular events associated with a neuronal phenotype and the mechanisms by which they do so have not been clearly defined.

A key aspect of neuronal differentiation that has not been examined in detail with regard to the actions of growth factors and their receptors is the induction of voltage-dependent sodium (Na) channels, which play a central role in the production and propagation of action potentials (Hodgkin and Huxley, 1952). The influence of growth factors on $\mathrm{Na}$ channel expression, as evidenced by the NGF induction of $\mathrm{Na}$ channel expression in rat pheochromocytoma (PC12) cells (Dichter et al., 1977; Mandel et al., 1988; Fanger et al., 1993), provides not only an avenue for identifying steps crucial to the ability of growth factors to induce neuronal differentiation (for discussion, see Chao, 1992b), but also a means of understanding processes fundamental to nervous system development. In particular, as opposed to many of the characterized responses of PC1 2 cells to NGF, induction of $\mathrm{Na}$ channel expression by NGF is independent of ras activity (D'Arcangelo and Haleguoa, 1993; Fanger et al., 1993), making analysis of $\mathrm{Na}$ channel induction useful for understanding the nature of this apparently biologically important (Borasio et al., 
1993), yet less understood facet of growth factor-mediated differentiation.

As an approach to understanding regulation of neuronal $\mathrm{Na}$ channel expression by growth factors and their receptors, we have analyzed $\mathrm{Na}$ channel expression in $\mathrm{PC} 12$ cells. In response to NGF, PCl2 cells acquire characteristics of sympathetic neurons during a transformation that includes cessation of cell division, ncuritc extension, and increased $\mathrm{Na}$ channel expression (for reviews, see Greene and Tischler, 1982; Halegoua et al., 1991). PC1 2 cells express the type II Na channel $\alpha$-subunit gene (Mandel et al., 1988; Fanger et al., 1993), one of the four $\alpha$-subunit genes (type I, II, IIa, and III) expressed in the brain that have been shown to encode functional $\mathrm{Na}$ channels (Noda et al., 1986; Auld et al., 1988; Suzuki et al., 1988). Mechanisms governing neuronal Na channel expression are largely unknown, although transcriptional, translational, and posttranslational events all appear to play a role (Wollner et al., 1988; Scheinman et al., 1989; Maue et al., 1990; Ginty et al., 1992) and may be important in determining the distinct pattern of type II $\alpha$-subunit expression during development (Beckh et al., 1989; for review, see Mandel, 1992). In the present studies, PC1 2 cells provided a common neuronal cellular context in which to determine the relative abilities of various endogenously and exogenously expressed RTKs to induce type II Na channel expression, with the results highlighting the specificity arising from differences in their intrinsic properties.

\section{Materials and Methods}

Cell culture. Cells were maintained in a humidified $\mathrm{CO}_{2}$ environment in DMEM (Dulbecco's Modified Eagle's Medium) containing $100 \mathrm{U} / \mathrm{ml}$ penicillin and $100 \mu \mathrm{g} / \mathrm{ml}$ streptomycin (GIBCO Laboratories, Grand Island, NY). The culture medium for the 6-15 and 6-24 sublines, and the wild-type PC12 cells from which they were generated (obtained courtesy of D. Kaplan, NCI-Frederick Cancer Center, Frederick, MD), contained $10 \%$ fetal bovine serum (FBS) and $5 \%$ heat inactivated horse serum (HS) (GIBCO Laboratories, Grand Island, NY). The medium for the trkB/PC1 2 cells and the wild-type cells they were generated from (obtained courtesy of G. Yancopoulos, Regeneron Pharmaceuticals, Tarrytown, NY) contained 6\% FBS and 6\% HS. For the PC-PDGFR102, PC-PDGFR-111, and PC-NEO-102 cells (obtained courtesy of L. Heasley, Univ. Colorado School of Medicine, Denver, $\mathrm{CO}$ ) the medium contained $5 \%$ plasma-derived FBS and $5 \%$ plasma-derived HS (Cocalico Biologicals, Reamstown, PA). Medium for the 6-15, 6-24, trkB/PC12, PC-PDGFR-102, PC-PDGFR-111, and PC-NEO-102 cells contained $250 \mu \mathrm{g} / \mathrm{ml} \mathrm{G} 418$ (GIBCO Laboratories, Grand Island, NY). Cells were plated and maintained on $150 \mathrm{~mm}$ (ODC assays), $100 \mathrm{~mm}$ (RNA analysis), or $35 \mathrm{~mm}$ (electrophysiology) tissue culture dishes (Falcon Labware, Becton Dickinson, Lincoln Park, NJ). In cases where $100 \mathrm{ng} / \mathrm{ml}$ $7 \mathrm{~S}$ NGF, $100 \mathrm{ng} / \mathrm{ml} \mathrm{EGF,} 30 \mathrm{ng} / \mathrm{ml}$ PDGF (Upstate Biotechnology, Plattsburg, NY), $100 \mathrm{ng} / \mathrm{ml}$ BDNF (Regeneron Pharmaceuticals, Tarrytown, NY), or $300 \mathrm{~nm}$ insulin (Sigma Chemical Co., St. Louis, MO) was included, fresh growth factor was added every other day when the media was changed.

Ornithine decarboxylase assay. Cells were plated at $\sim 60 \%$ confluency $2 \mathrm{~d}$ prior to the assay. Cells were washed twice with DMEM containing $1 \% \mathrm{HS}$ and treated for $5 \mathrm{hr}$ in DMEM containing $1 \% \mathrm{HS}$ and the indicated growth factors. Cells were then rinsed with ice cold PBS (130 mM NaCl, $10 \mathrm{~mm} \mathrm{Na}_{2} \mathrm{HPO}_{4}, 10 \mathrm{~mm} \mathrm{NaH}_{2} \mathrm{PO}_{4}, \mathrm{pH}$ 7.2), harvested in PBS by trituration, pelleted by brief centrifugation, and then resuspended and lysed by sonication in homogenizing buffer $(50 \mathrm{mM} \mathrm{Na}-$ $\mathrm{H}_{2} \mathrm{PO}_{4}, 0.1 \mathrm{~mm}$ EDTA, $5 \mathrm{~mm}$ dithiothreitol, and $40 \mathrm{~mm}$ pyridoxal phosphate, $\mathrm{pH}$ 7.2). Cellular debris was removed by centrifugation and the protein concentration of the supernatant adjusted to $\sim 1 \mathrm{mg} / \mathrm{ml}$. Ornithine decarboxylase activity in the supernatant was assayed by the method of Djurhuus (1981), with the conversion of ${ }^{3} \mathrm{H}$-ornithine (Amersham, Arlington Heights, IL) to ${ }^{3} \mathrm{H}$-putrescine assayed at $0,20,40,60$, and $80 \mathrm{~min}$ by spotting an aliquot of the assay mixture on to P81 ionexchange paper (Whatman, Hillsboro, OR) and washing in $0.1 \mathrm{M} \mathrm{NH}_{4} \mathrm{OH}$;
pH 11.3. Specific activities were determined from slopes calculated by linear regression.

RNA isolation and analysis. Total cellular RNA was isolated by the method of Chirgwin et al. (1979). Northern blot analysis and preparation of ${ }^{32} \mathrm{P}-\mathrm{UTP}$-labeled $\mathrm{cRNA}$ probes specific for $\mathrm{Na}$ channel and cyclophilin mRNA were done as in our previous studies (Ginty et al., 1992; Fanger et al., 1993). A random primed cDNA probe for fos mRNA was generated using ${ }^{32}$ P-CTP (Amersham, Arlington Heights, IL), a commercially available kit (Bethesda Research Laboratories, Grand Island, NY), and a fos cDNA (courtesy of J. Belasco and M. Greenberg, Harvard Medical School, Boston, MA). RNase protection analysis was performed essentially as described by Hod (1992). The Na channel type specific cRNA probe and cyclophilin specific cRNA probe were generated using ${ }^{32} \mathrm{P}-\mathrm{UTP}$ and hybridized with RNA as described in our previous studies (Fanger et al., 1993), with the exception that the samples were digested with RNase for $24 \mathrm{hr}$ at $6^{\circ} \mathrm{C}$ before being separated on a $6 \%$ acrylamide gel and exposed to Kodak XAR film for $24 \mathrm{hr}$ at $-80^{\circ} \mathrm{C}$. The NIH IMAGE program was used for densitometric analysis of the autoradiographic signals representing the $\mathrm{Na}$ channel and cyclophilin mRNAs.

Electrophysiological recording and analysis. Whole-cell patch-clamp analysis of Na current density was done as in our earlier studies (Ginty et al., 1992; Fanger et al., 1993). Culture medium was replaced with a saline solution $\left(150 \mathrm{~mm} \mathrm{NaCl}, 5 \mathrm{~mm} \mathrm{KCl}, 1 \mathrm{~mm} \mathrm{CaCl}_{2}, 1 \mathrm{~mm} \mathrm{MgCl}\right.$, $6 \mathrm{~mm}$ HEPES, $6 \mathrm{~mm}$ glucose, $\mathrm{pH}$ 7.2), and recordings were made using a List EPC-7 patch-clamp amplifier (Medical Systems Corp.) and patch electrodes $(3-7 \mathrm{M} \Omega)$ filled with an internal solution designed to minimize the contribution of other voltage-activated currents $(140 \mathrm{~mm} \mathrm{CsCl}, 10$ mM EGTA, 10 mM HEPES). Electronic compensation was used to reduce the effective series resistance and the time constant of membrane charging, and to provide measurements of access resistance and cell membrane capacitance. Series resistance compensation of $50-70 \%$ was routinely used and reduced estimated series resistance errors to $5 \mathrm{mV}$ or less. Voltage commands were applied and current measurements were made using an Atari computer-based acquisition system (Instrutech Corp., Elmont, NY). Cells were held at $-80 \mathrm{mV}$ and every $3 \mathrm{sec}$ the membrane potential stepped through a $40 \mathrm{msec}$ prepulse to $-120 \mathrm{mV}$, followed by a $20 \mathrm{msec}$ depolarizing test pulse to a potential between $-60 \mathrm{mV}$ and $+30 \mathrm{mV}$. Current signals were low pass filtered at $10 \mathrm{kHz}$, digitized at $20 \mathrm{kHz}$ for storage, and digitally filtered at $2 \mathrm{kHz}$ during analysis. Linear leakage currents and capacity transients were subtracted with scaled pulse $(\mathrm{P} / 4)$ routines. The maximum $\mathrm{Na}$ current amplitude elicited, along with the measurement of cell membrane capacitance, was used to calculate $\mathrm{Na}$ current density. Statistical significance was determined using a two-tailed Student's $t$ test.

\section{Results}

Type II Na channel expression in PC12 cells can be regulated through different trk tyrosine kinase receptors

The discovery of other NGF-related neurotrophins, such as BDNF and NT-3 (Liebrock et al., 1989; Hohn et al., 1990; Maisonpierre et al., 1990; for review, see Thoenen, 1991), in addition to the discovery of other members of the trk tyrosine kinase receptor family, such as trkB and trkC (Klein et al., 1989; Lamballe et al., 1991; Middlemas et al., 1991; Tsoulfas et al., 1993; for review, see Chao, 1992a), has led to considerable interest in the biological capabilities of these neurotrophins and receptors. To determine if the activation of $\operatorname{trkB}$ or trkC receptors can cause changes in neuronal $\mathrm{Na}$ channel expression, we assayed the effects of $\mathrm{BDNF}$ and NT-3 on Na channel expression in $\mathrm{PC} 12$ sublines stably expressing either trkB or trkC receptors (Ip et al., 1993; Tsoulfas et al., 1993). We also analyzed $\mathrm{Na}$ channel expression in two PC12 sublines in which trkA has been stably overexpressed (Hempstead et al., 1992). Using c-fos induction and neurite outgrowth as indications of the general responsiveness of the cells to the NGF, BDNF, or NT-3 treatments (Fig. 1), the cells used in our analysis responded as expected based on previous studies (Hempstead et al., 1992; Ip et al., 1993; Tsoulfas et al., 1993). As predicted for cells that do not express trkB or trkC, wild-type $\mathrm{PC} 12$ cells did not respond to 
A

B trkB/PC12

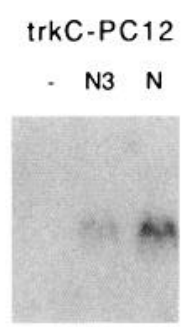

C

B $\mathrm{N}$

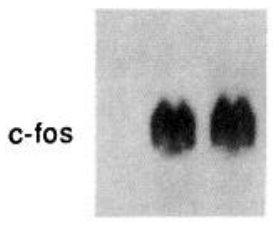

D

untreated
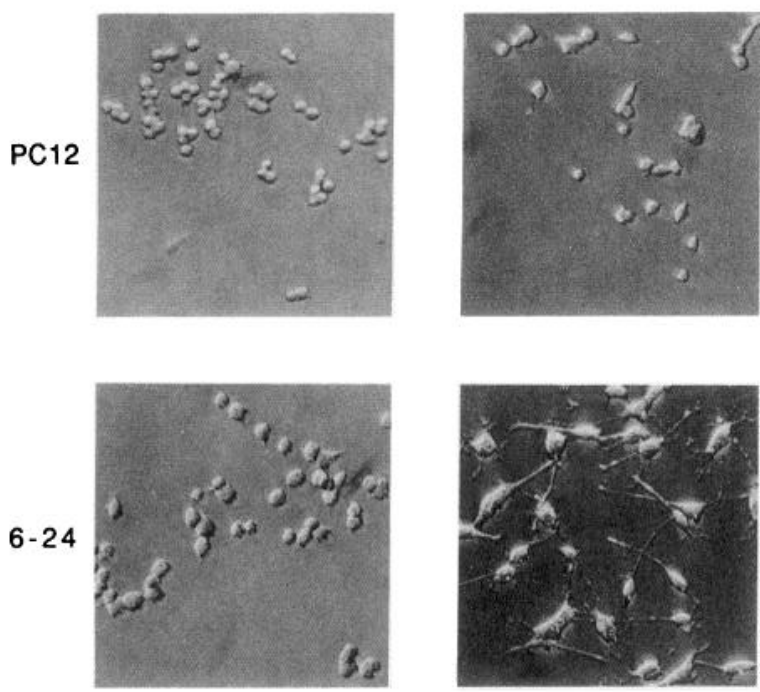

Figure 1. Neurotrophin-mediated responses of PC12 sublines stably expressing members of the trk family of tyrosine kinase receptors. In $A-C$, Northern blot hybridization was used to analyze c-fos mRNA levels in $20 \mu \mathrm{g}$ samples of RNA from cells maintained in the absence or presence of neurotrophins for $30 \mathrm{~min}$ (except trkC-PC12 cells, which were treated for $60 \mathrm{~min}$ ). The c-fos signals are shown after $12 \mathrm{hr}$ exposure to film. The position and molecular sizes $(\mathrm{kb})$ of a commercially available RNA ladder (Bethesda Research Laboratories, Grand Island, NY) are shown on the right. In $A$, RNA samples were from trkB/PC12 cells either untreated (-) or treated with $100 \mathrm{ng} / \mathrm{ml} \mathrm{BDNF}(B)$ or $100 \mathrm{ng} /$ $\mathrm{ml}$ NGF $(N)$. In $B$, RNA samples were from trkC-PC12 cells either untreated (-) or treated with $100 \mathrm{ng} / \mathrm{ml} \mathrm{NT}-3(N 3)$ or $100 \mathrm{ng} / \mathrm{ml} \mathrm{NGF}$ $(N)$. In $C$, RNA samples were from 6-24 cells either untreated (-) or treated with $100 \mathrm{ng} / \mathrm{ml} \mathrm{NGF}(N)$. In $D$, photographs illustrate the accelerated neurite outgrowth from 6-24 cells, as compared to the wildtype PC12 cells, when treated for $1 \mathrm{~d}$ with $100 \mathrm{ng} / \mathrm{ml} \mathrm{NGF}$. Cell bodies in the untreated PC12 cells are approximately $15 \mu \mathrm{m}$ in diameter.

BDNF or NT-3 with either an increase in c-fos mRNA or neurite outgrowth (data not shown). In contrast, the trkB-expressing PC1 2 cells responded to either NGF or BDNF with an increase in c-fos mRNA expression (Fig. 1 $\mathrm{A}$ ), flattening of the cell body, and extensive neurite outgrowth (data not shown). Similarly, NT-3 caused increases in c-fos mRNA expression (Fig. $1 B$ ) and neurite outgrowth (data not shown) in the $\mathrm{PC} 12$ cells stably expressing trkC. In PC1 2 cells overexpressing trkA, the increases in c-fos mRNA (Fig. 1C) and the accelerated neurite outgrowth in response to NGF (Fig. 1D) were consistent with the previous characterization of these cells (Hempstead et al., 1992).

To determine whether activation of trkB or trkC could increase type II Na channel gene expression, RNAse protection assays were used to analyze RNA from PC12 sublines treated with either NGF, BDNF, or NT-3 (Fig. 2), using previously developed procedures and a ${ }^{32} \mathrm{P}$-labeled probe specific for type II Na channel mRNA (Fanger et al., 1993). Given that cyclophilin mRNA is constitutively expressed in PC12 cells and unaffected by growth factor treatment (Machida et al., 1989), a radiolabeled probe specific for cyclophilin mRNA was also included in the assays and the cyclophilin mRNA signal used as an internal control for variations in RNA loading. In wild-type PC1 2 cells, treatment with BDNF for $7 \mathrm{~d}$ failed to increase type II Na channel mRNA expression, while exposure to NGF for $7 \mathrm{~d}$ caused a threefold increase (Fig. $2 A$ ). In contrast, treatment of the trkB-expressing PC12 cells with BDNF for $7 \mathrm{~d}$ caused a 2.3-fold increase in type II Na channel mRNA (Fig. $2 A$ ). In PC1 2 cells expressing trkC receptors, there was an increase in type II Na channel mRNA expression after $4 \mathrm{~d}$ treatment with either NGF (2.9-fold) or NT-3 (2.0-fold) (Fig. 2B). The trkBand trkC-mediated increases in type II Na channel mRNA expression appeared to be due to specific signaling capabilities of these receptors and not simply the consequence overexpressing a tyrosine kinase receptor, since overexpression of trkA in $\mathrm{PC1} 2$ cells did not appreciably alter the NGF-mediated induction of type II Na channel mRNA when compared to that occurring in wild-type cells. In both trkA-overexpressing sublines that were analyzed (6-15 and 6-24), the time course of the type II Na channel mRNA induction was not accelerated, nor was the extent of induction enhanced. In fact, the induction of type II Na channel mRNA was relatively modest (though within the range normally observed), perhaps due to slightly elevated levels of type II Na channel mRNA in these cells in the absence of NGF (Fig. 2C).

Whole-cell patch-clamp analysis was used to determine if any of these changes in $\mathrm{Na}$ channel gene expression were accompanied by changes in functional $\mathrm{Na}$ channel expression. Using previously developed procedures (Fanger et al., 1993), cells grown on tissue culture plastic in the presence or absence of growth factors for $7 \mathrm{~d}$ were held at $-80 \mathrm{mV}$, the membrane potential prepulsed to $-120 \mathrm{mV}$, and the responses to step depolarizations between $-60 \mathrm{mV}$ and $+30 \mathrm{mV}$ measured in order to determine the peak Na current (Fig. 3). Cell membrane capacitance was determined as an estimate of cell size, and from the measurements of peak $\mathrm{Na}$ current and cell membrane capacitance, the Na current density was estimated. As expected for the wild-type PC12 cells, exposure to NGF for $7 \mathrm{~d}$ caused the proportion of cells with appreciable $\mathrm{Na}$ currents $(>50 \mathrm{pA})$ to increase (from 10/26 to 23/23) and caused significant $(p<0.01$ ) increases in the magnitude of the $\mathrm{Na}$ currents and the average $\mathrm{Na}$ current density (Fig. $3 A, C$ ), while exposure to BDNF for 7 $\mathrm{d}$ had no effect (Fig. $3 A, C$ ). In contrast, BDNF had a dramatic effect on the trkB-expressing PC12 cells. In these cells, the proportion of BDNF-treated cells with appreciable Na currents (20/ $20)$ was similar to that observed in response to NGF $(22 / 22)$, and there were significant $(p<0.01)$ increases in the magnitude of the Na currents, average cell size, and average Na current density (Fig. $3 B, C$ ). Although the increase in Na current density in response to BDNF was less than observed in the cells in response to NGF (Fig. $3 C$ ), the difference was not statistically significant, and when coupled with the changes in type II Na channel mRNA expression (Fig. $2 A$ ), the $\sim 3$-fold increase in $\mathrm{Na}$ current density in the BDNF-treated cells indicates that activation of trkB can result in increases in $\mathrm{Na}$ channel expression.

The effect of NGF on functional $\mathrm{Na}$ channel expression was 
A

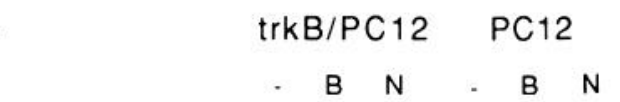

Type II Na protected
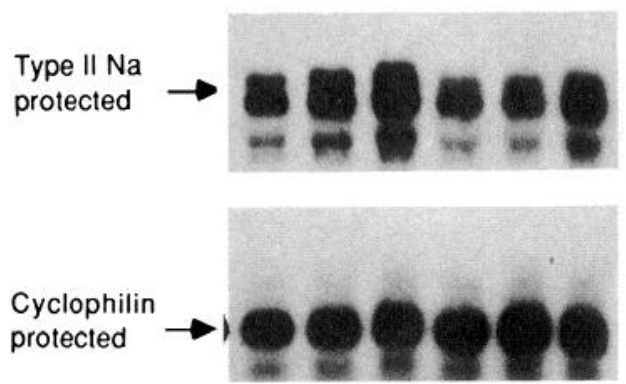

B

\section{trkC-PC12}

N3 N

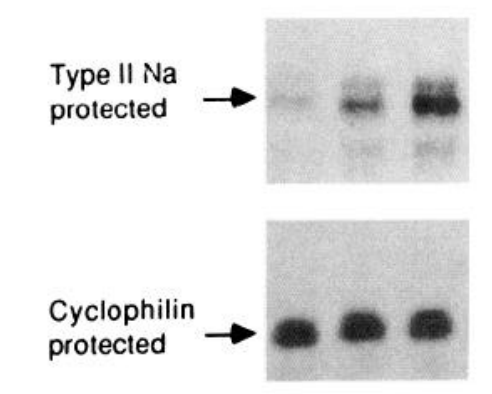

C

$6-15$
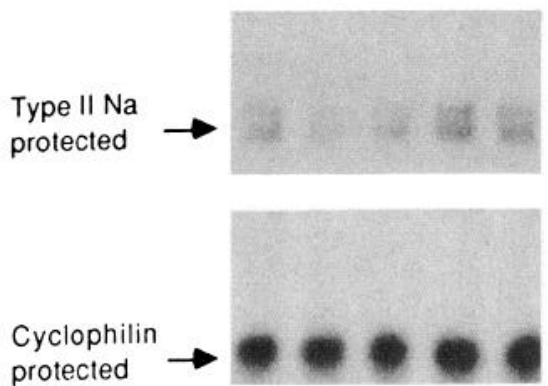

Figure 2. Neurotrophin-mediated induction of type II Na channel mRNA in PC12 sublines stably expressing members of the trk family of tyrosine kinase receptors. In $A-C$, RNase protection assays were used to analyze type II Na channel and cyclophilin mRNA levels in $20 \mu \mathrm{g}$ samples of RNA from cells maintained in the absence or presence of neurotrophins. Probes specific for type II Na channel mRNA and for cyclophilin mRNA were used, with the signals representing cyclophilin mRNA, which is constitutively expressed in PC12 cells and unaffected by growth factor treatment, used as an internal control for variations in RNA loading (see Materials and Methods). Only the signals representing the protected mRNA fragments are shown. Signals representing $\mathrm{Na}$ channel mRNA are shown after $24 \mathrm{hr}$ exposure to film; signals representing cyclophilin mRNA are shown after $30 \mathrm{~min}$ exposure to film. In $A$, RNA samples were from trkB/PC12 cells or wild-type PC12 cells either untreated $(-)$ or treated for $7 \mathrm{~d}$ with $100 \mathrm{ng} / \mathrm{ml}$ BDNF $(B)$ or $100 \mathrm{ng} / \mathrm{ml} \mathrm{NGF}(N)$. In $B$, RNA samples were from trkC-PC1 2 cells either untreated $(-)$ or treated for $4 \mathrm{~d}$ with $100 \mathrm{ng} / \mathrm{ml} \mathrm{NT}-3(N 3)$ or $100 \mathrm{ng} / \mathrm{ml}$ NGF $(N)$. In $C$, RNA samples were from 6-15 cells either untreated $(-)$ or treated with $100 \mathrm{ng} / \mathrm{ml} \mathrm{NGF}$ for $1-7 \mathrm{~d}$.
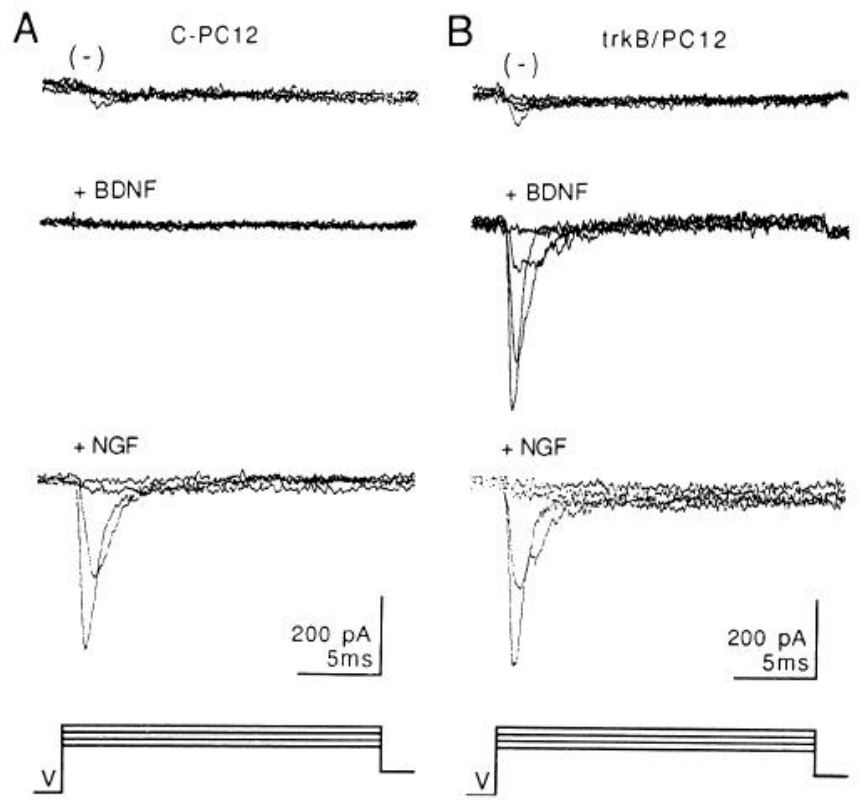

C
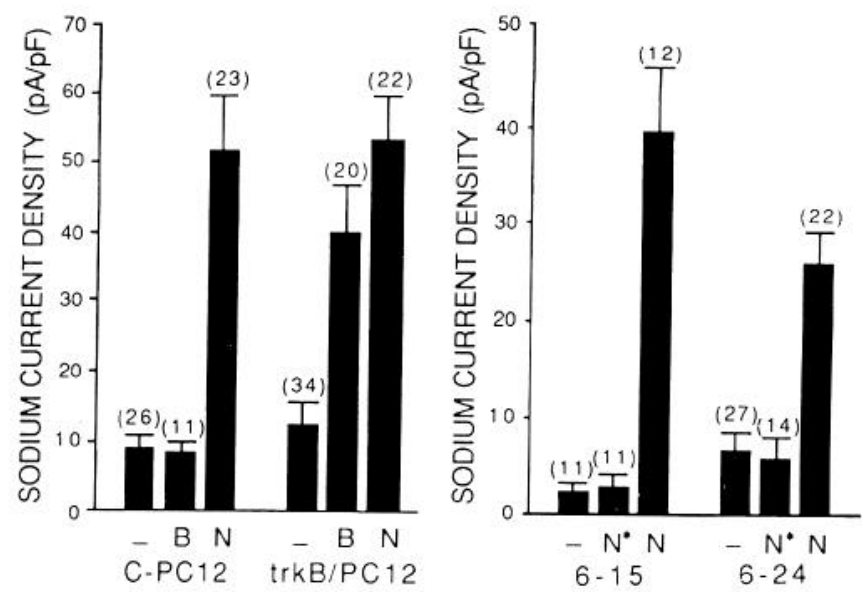

Figure 3. Neurotrophin-mediated increases in Na current density in PC12 sublines stably expressing members of the trk family of tyrosine kinase receptors. In $A$ and $B$ are representative recordings of voltagedependent $\mathrm{Na}$ currents in wild-type $\mathrm{PC} 12$ cells $(C-P C 12)$ and trkB/ PC12 cells that were either untreated, or treated for $7 \mathrm{~d}$ with $100 \mathrm{ng} /$ $\mathrm{ml}$ BDNF or $100 \mathrm{ng} / \mathrm{ml} \mathrm{NGF}$. Superimposed current records illustrate the response to depolarizing pulses to $-40,-30,-20$, and $-10 \mathrm{mV}$, from a prepulse potential of $-120 \mathrm{mV}$ and holding potential of -80 $\mathrm{mV}$. $C$, Average Na current density in wild-type PC12 cells $(C-P C 12)$ and $\operatorname{trkB} / \mathrm{PC} 12$ cells that were either untreated $(-)$ or treated for $7 \mathrm{~d}$ with $100 \mathrm{ng} / \mathrm{ml}$ BDNF $(B)$ or $100 \mathrm{ng} / \mathrm{ml} \mathrm{NGF}(N)$. $D$, Average Na current density in the 6-15 and 6-24 sublines of PC12 cells when either untreated $(-)$ or treated with $100 \mathrm{ng} / \mathrm{ml} \mathrm{NGF}$ for $1 \mathrm{~d}\left(N^{*}\right)$ or $7 \mathrm{~d}(N)$. In $C$ and $D$, the number of cells in each group is in parentheses above the bars. Error bars represent the SEM. Cell membrane capacitance (mean \pm SEM) was $9.2 \pm 0.5 \mathrm{pF}$ for untreated, $8.4 \pm 0.6 \mathrm{pF}$ for BDNFtreated, and $22.1 \pm 1.2 \mathrm{pF}$ for NGF-treated wild-type PC12 cells, 9.8 $\pm 0.6 \mathrm{pF}$ for untreated, $15.0 \pm 1.0 \mathrm{pF}$ for BDNF-treated, and $18.3 \pm$ $1.0 \mathrm{pF}$ for NGF-treated trkB/PC12 cells, $7.6 \pm 0.6 \mathrm{pF}$ for untreated, $38.7 \pm 7.4 \mathrm{pF}$ for NGF-treated $(1 \mathrm{~d})$, and $27.8 \pm 1.6 \mathrm{pF}$ for NGFtreated $(7 \mathrm{~d}) 6-15$ cells, $12.3 \pm 0.5 \mathrm{pF}$ for untreated, $32.4 \pm 4.6 \mathrm{pF}$ for NGF-treated $(1 \mathrm{~d})$, and $54.1 \pm 9.4 \mathrm{pF}$ for NGF-treated (7 d) 6-24 cells. 
A

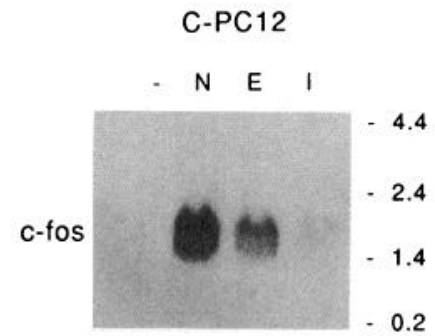

B

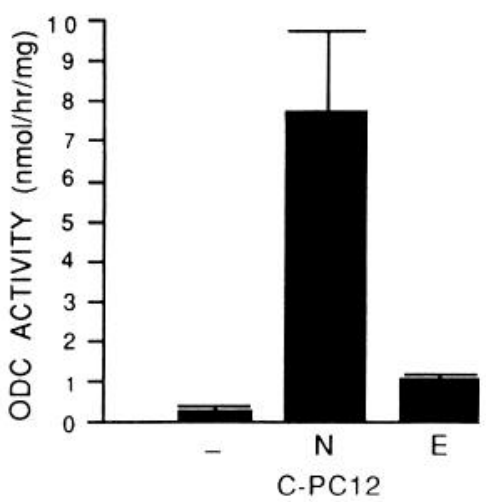

Figure 4. Responsiveness of wild-type PC12 cells to growth factor treatment. $A$, Northern blot analysis of c-fos mRNA expression in 20 $\mu \mathrm{g}$ samples of RNA from cells that were either untreated $(-)$ or treated for $30 \mathrm{~min}$ with $100 \mathrm{ng} / \mathrm{ml} \mathrm{NGF}(N), 100 \mathrm{ng} / \mathrm{ml} \mathrm{EGF}(E)$, or $300 \mathrm{nM}$ insulin $(I)$. The position and molecular sizes of a commercially available RNA ladder (Bethesda Research Labs) are shown on the right. B, Ornithine decarboxylase $(O D C)$ activity in cells that were either untreated (-) or treated for $5 \mathrm{hr}$ with $100 \mathrm{ng} / \mathrm{ml} \mathrm{NGF}$ or $100 \mathrm{ng} / \mathrm{ml}$ EGF. Error bars represent the SEM.

also determined in the 6-15 and 6-24 sublines overexpressing trkA. After treatment with NGF for $1 \mathrm{~d}$, there was an increase in the proportion of cells with appreciable $(>50 \mathrm{pA}) \mathrm{Na}$ currents (from $0 / 11$ to $6 / 11$ and $15 / 27$ to $11 / 14$, respectively). However, because of large increases in cell size, the Na current density remained essentially unchanged (Fig. $3 D$ ), consistent with the lack of change in $\mathrm{Na}$ current density in wild-type PC12 cells after $1 \mathrm{~d}$ treatment (data not shown). NGF treatment of the 6-15 and 6-24 cell lines for $7 \mathrm{~d}$ resulted in further increases in the proportion of cells (11/12 and $22 / 22$, respectively) with appreciable $\mathrm{Na}$ currents, as well as significant $(p<0.01)$ increases in average $\mathrm{Na}$ current magnitude, cell size, and $\mathrm{Na}$ current density (Fig. 3D). Although the Na current densities in both sublines were comparable to those detected in wild-type $\mathrm{PC} 12$ cells, the Na current density in the NGF-treated 6-24 cells was lower than in NGF-treated 6-15 cells, presumably due to the extremely large increase in cell size that occurred in this PC12 subline (Fig. 3). Despite this variability, the overall results suggest that neither the rate nor the extent of induction of functional $\mathrm{Na}$ channels was appreciably influenced by overexpression of the trkA receptor.

\section{Differential regulation of type II Na channel expression in} PC12 cells by insulin, EGF, and NGF

Insulin, EGF, and NGF mediate their effects on PC12 cells through tyrosine kinase receptors, yet have clearly different biological effects, with insulin and EGF promoting growth and proliferation and NGF causing cessation of cell division and neuronal differentiation (for discussion, see Saltiel and Decker, 1991; Chao, 1992b). To determine whether the difference in the biological effects of these factors includes differences in the regulation of $\mathrm{Na}$ channel expression, we compared the effects of insulin, EGF, and NGF on Na channel expression in PC12 cells. The two different sublines of wild-type PC12 cells used in the analysis responded to all three factors, as indicated by increases in c-fos mRNA (Fig. 4A) and/or ornithine decarboxylase (ODC) activity (Fig. $4 B$ ). In addition, treatment of the wild-type PC12 cells with insulin elicited a rapid increase in the tyrosine phosphorylation of both the $\beta$-subunit of the insulin receptor and a key insulin receptor substrate (IRS-1) (Fanger, Kuhne, Lienhard, and Maue, unpublished observations). The results were consistent with previous studies (Huff et al., 1981), including those using PC1 2 cells expressing roughly equivalent numbers of functional receptors for these factors (Ohmichi et al., 1993).

To determine if the differential effects of insulin, EGF, and NGF included corresponding differences in Na channel mRNA expression, wild-type $\mathrm{PC} 12$ cells treated with these factors were analyzed using two different methods and two different probes for Na channel mRNA. In addition, because it has been postulated that the transient nature of the cellular responses to EGF receptor activation may be the basis for the differences in the actions of EGF and NGF (Heasley and Johnson, 1992; Qiu and Green, 1992), Na channel mRNA levels were analyzed in cells treated over a time course of 1-7 d. Northern blot analysis was carried out as in our previous studies (Ginty et al., 1992; Fanger et al., 1993), using a ${ }^{32} \mathrm{P}$-labeled antisense probe that corresponds to a coding region highly conserved among $\mathrm{Na}$ channel genes (Mandel et al., 1988) and recognizes multiple types of $\mathrm{Na}$ channel mRNA (Cooperman et al., 1987; Sills et al., 1989). In response to NGF, there was a clearly detectable increase in $\mathrm{Na}$ channel mRNA by the earliest time assayed ( $24 \mathrm{hr})$, with a steady increase in Na channel mRNA throughout the time period investigated (Fig. $5 A$ ). In contrast, insulin did not cause an increase in $\mathrm{Na}$ channel mRNA (data not shown), while EGF caused only a slight increase in Na channel mRNA that gradually developed over the period of treatment (Fig. $5 A$ ). RNase protection assays were then used to analyze RNA from NGF-, insulin-, and EGF-treated cells, using previously developed procedures and a ${ }^{32} \mathrm{P}$-labeled probe specific for type II Na channel mRNA (Fanger et al., 1993). Consistent with the results from the Northern blot hybridizations, NGF caused an increase in type II Na channel mRNA that was detectable at the earliest time assayed $(24 \mathrm{hr})$ and gradually increased throughout the NGF treatment (Fig. $5 B$ ), while insulin failed to elicit an increase (data not shown), and EGF caused only a relatively small increase in type II Na channel mRNA over the time period investigated (Fig. $5 B$ ). The average results from several independent experiments are shown in Figure 6, where the $\mathrm{Na}$ channel mRNA signals in the RNase protection assays and Northern blot hybridizations were quantitated by densitometry, normalized to the signals representing cyclophilin mRNA, and then plotted relative to the level of $\mathrm{Na}$ channel mRNA in the untreated cells. As shown, the results obtained using both assays were virtually identical. In wild-type PC1 2 cells, NGF treatment caused a significant $(p<0.05)$ increase in Na channel mRNA by $1 \mathrm{~d}(2.1-2.3$-fold), which gradually increased by $7 \mathrm{~d}(4.2-$ 4.6-fold) and remained significantly different $(p<0.01)$ from levels found in untreated cells (Fig. 6). This contrasts to insulin treatment, which did not cause a detectable increase at any time, 
A

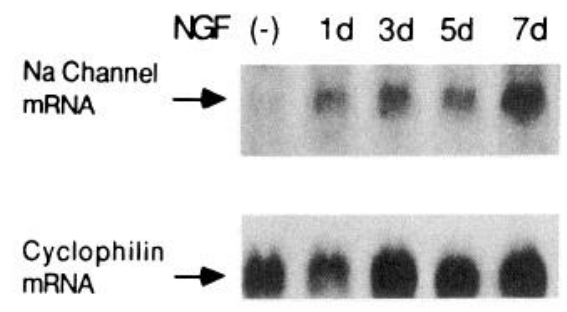

EGF (-) $1 d$ 3d $5 d \quad 7 d$
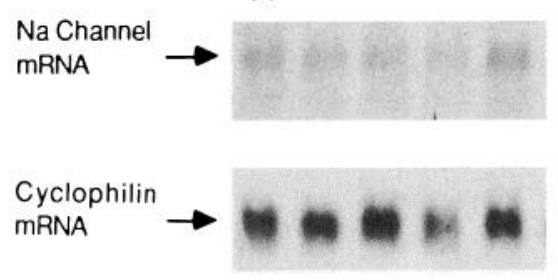

B

$$
\text { NGF (-) 1d 3d 5d 7d }
$$
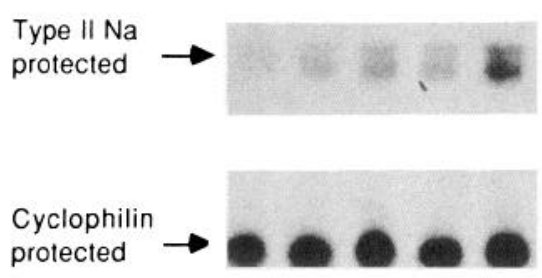

EGF (-) $1 d \quad 3 d \quad 5 d \quad 7 d$

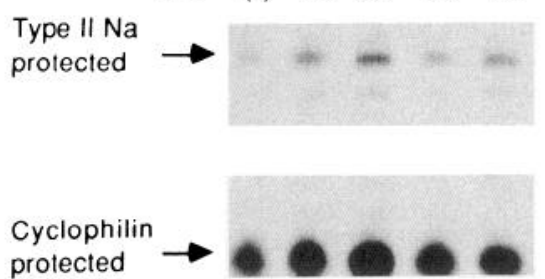

Figure 5. Time course of induction of Na channel mRNA in wildtype PC12 cells treated with NGF or EGF. Samples of RNA from cells that were either untreated (-) or treated with $100 \mathrm{ng} / \mathrm{ml} \mathrm{NGF}$ or 100 $\mathrm{ng} / \mathrm{ml}$ EGF for $1-7 \mathrm{~d}$ were analyzed using Northern blot hybridization ( $A, 40 \mu \mathrm{g}$ samples) and RNase protection assays ( $B, 20 \mu \mathrm{g}$ samples). In $B$, probes specific for type II Na channel mRNA and for cyclophilin mRNA were used, with the signals representing cyclophilin mRNA, which is constitutively expressed in PC12 cells and unaffected by growth factor treatment, used as an internal control for variations in RNA loading (see Materials and Methods). Only the signals representing the protected mRNA fragments are shown. In both $A$ and $B$ representative experiments are shown, with signals representing Na channel mRNA shown after $24 \mathrm{hr}$ exposure to film and signals representing cyclophilin mRNA shown after $30 \mathrm{~min}$ exposure to film.

and treatment with EGF, which caused a gradual increase in $\mathrm{Na}$ channel mRNA that was significantly different $(p<0.01)$ from the levels in untreated cells only after treatment for $7 \mathrm{~d}$, when an $\sim 1.7$-fold induction was detected (Fig. 6). Thus, both

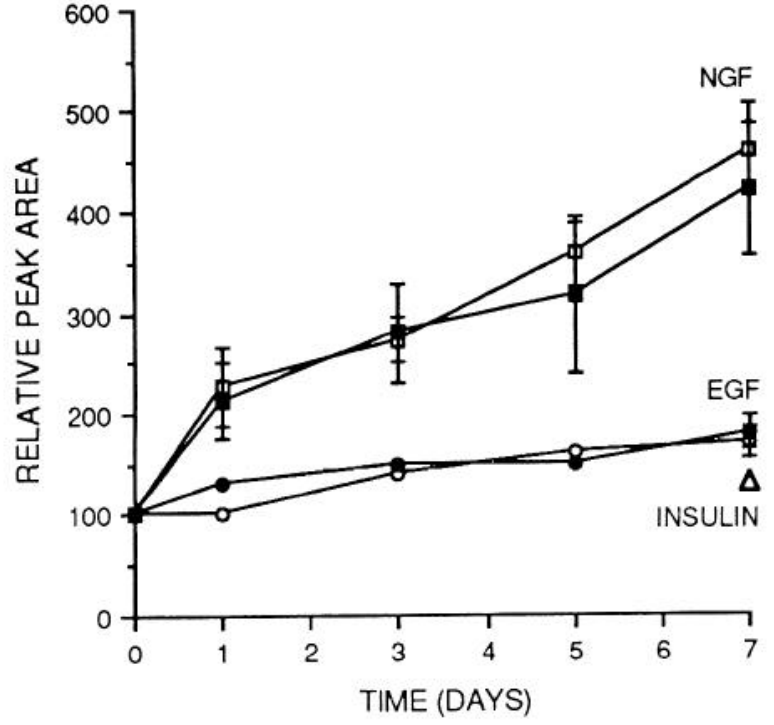

Figure 6. Relative time course of induction of $\mathrm{Na}$ channel mRNA in wild-type PC12 cells treated with NGF, EGF, or insulin. Na channel mRNA in cells treated with NGF (squares), EGF (circles), or insulin (triangles), was detected by Northern blot hybridization (open symbols) or by RNase protection assay using a type II Na channel specific probe (solid symbols). The signals were quantitated by densitometry, normalized to the signals representing the constitutively expressed cyclophilin mRNA to correct for variations in RNA loading, and then plotted relative to the level of $\mathrm{Na}$ channel mRNA in untreated cells. The average results from three separate experiments are shown, with error bars (representing the SEM) shown where the levels of expression were significantly greater than detected in untreated cells.

methods detected differential effects of these factors on Na channel mRNA expression and slight, yet detectable effects of EGF on Na channel mRNA levels. Furthermore, the close agreement between the changes in $\mathrm{Na}$ channel mRNA levels detected in the Northern blot experiments and the changes in type II $\mathrm{Na}$ channel mRNA levels detected in the RNase protection assays also indicated that the induction of type II Na channel mRNA could account for the increase in $\mathrm{Na}$ channel mRNA in $\mathrm{PC} 12$ cells during prolonged exposure to NGF and EGF.

To determine if the changes in Na channel mRNA in response to NGF and EGF were accompanied by corresponding changes in the expression of functional $\mathrm{Na}$ channels, whole-cell patch clamp recordings were used to measure the effects of EGF on $\mathrm{Na}$ current density in the wild-type PC12 cells used in the analysis of Na channel mRNA. In two different wild-type lines, there were relatively low levels of $\mathrm{Na}$ channel expression in the untreated cells, as indicated by the proportion of cells with appreciable $(>50 \mathrm{pA}) \mathrm{Na}$ currents $(9 / 20,10 / 26)$, the average magnitude of the Na currents, and the Na current density (Fig. 7A). After treatment with $100 \mathrm{ng} / \mathrm{ml} \mathrm{NGF}$ for $7 \mathrm{~d}$, there was the expected increase in the proportion of cells with appreciable currents $(21 / 21,23 / 23)$, as well as significant $(p<0.01)$ increases in the average magnitude of the $\mathrm{Na}$ currents, cell size, and $\mathrm{Na}$ current density, the latter increasing 5-6-fold in both sublines (Fig. $7 \mathrm{~A}$ ). In response to $100 \mathrm{ng} / \mathrm{ml} \mathrm{EGF}$ for $7 \mathrm{~d}$, there was an intermediate increase in the proportion of cells with appreciable Na currents $(16 / 21,14 / 21)$ and a $2.0-2.5$-fold incrcase in the average magnitude of the Na currents. Coupled with only a slight increase in cell size (as indicated by cell membrane capacitance), this resulted in a 2.0-2.5-fold increase in Na current density in 
A

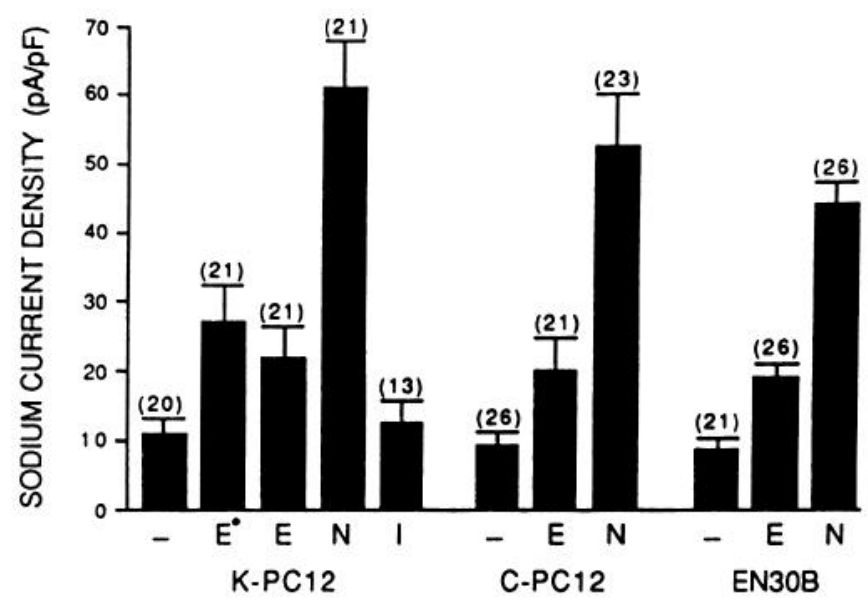

B

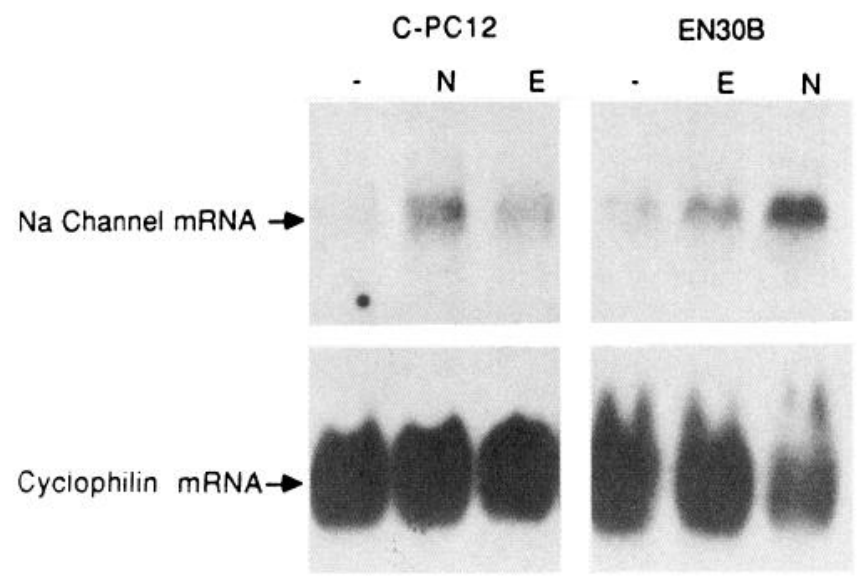

Figure 7. Na channel expression in wild-type PC12 cells and PC12 cells expressing an EGF receptor/p 75 chimeric receptor. $A$, Average $\mathrm{Na}$ current density in wild-type $\mathrm{PC} 12$ subclones $(K-P C 12, C-P C 12)$ and PC1 2 cells expressing an EGF receptor/p75 chimeric receptor $(E N 30 B)$. Cells were either untreated (-) or treated for $7 \mathrm{~d}$ with $10 \mathrm{ng} / \mathrm{ml}$ EGF $\left(E^{*}\right), 100 \mathrm{ng} / \mathrm{ml} \operatorname{EGF}(E), 100 \mathrm{ng} / \mathrm{ml} \mathrm{NGF}(N)$, or $300 \mathrm{~nm}$ insulin $(I)$. The number of cells in each group is in parentheses above the bars. Error bars represent the SEM. Cell membrane capacitance (mean \pm SEM) was $9.2 \pm 0.5 \mathrm{pF}$ for untreated, $9.3 \pm 0.6 \mathrm{pF}$ for EGF-treated $(100 \mathrm{ng} / \mathrm{ml})$, and $22.1 \pm 1.2 \mathrm{pF}$ for NGF-treated C-PC1 2 cells, $8.2 \pm$ $0.8 \mathrm{pF}$ for untreated, $9.2 \pm 0.4 \mathrm{pF}$ for EGF-treated $(100 \mathrm{ng} / \mathrm{ml}), 9.1 \pm$ $0.5 \mathrm{pF}$ for EGF-treated $(10 \mathrm{ng} / \mathrm{ml}), 18.7 \pm 1.4 \mathrm{pF}$ for NGF-treated, and $7.6 \pm 0.6 \mathrm{pF}$ for insulin-treated $\mathrm{K}-\mathrm{PC} 12$ cells, $13.0 \pm 0.8 \mathrm{pF}$ for untreated, $23.2 \pm 1.2 \mathrm{pF}$ for EGF-treated, and $25.0 \pm 1.3 \mathrm{pF}$ for NGFtreated EN30B cells. $B$, Northern blot hybridization of total RNA (40 $\mu \mathrm{g})$ isolated from wild-type PC12 cells or EN30B cells. Cells were untreated $(-)$, or treated for $7 \mathrm{~d}$ with $100 \mathrm{ng} / \mathrm{ml} \mathrm{EGF}(E)$ or $100 \mathrm{ng} / \mathrm{ml}$ NGF $(N)$. Signals representing Na channel mRNA are shown after 24 hr exposure to film; signals representing cyclophilin mRNA are shown after $30 \mathrm{~min}$ exposure to film.

both sublines in response to EGF (Fig. $7 A$ ), clearly less than that induced by NGF and consistent with previous findings (Pollock et al., 1990). A similar increase in the proportion of cells with appreciable Na currents $(16 / 21)$, Na current magnitude, and $\mathrm{Na}$ current density was also observed in cells treated with $10 \mathrm{ng} / \mathrm{ml} \mathrm{EGF} \mathrm{(Fig.} \mathrm{7A).} \mathrm{The} \mathrm{results} \mathrm{were} \mathrm{not} \mathrm{limited} \mathrm{to}$ wild-type PC12 cells or the presence of a particular type of serum in the culture medium, since in a stably transfected subline of PC1 2 cells maintained in medium containing neomycin and different serum components (see Materials and Methods), the proportion of EGF-treated cells with appreciable $\mathrm{Na}$ currents $(14 / 23)$ was again between that found in untreated cells $(10 / 25)$ and in NGF-treated cells $(22 / 22)$, and there were $\sim 2$-fold increases in $\mathrm{Na}$ current magnitude and $\mathrm{Na}$ current density (see Fig. 10). The magnitude of these inductions was similar to the increases detected in the analysis of $\mathrm{Na}$ channel mRNA, and suggests that the modest increase in Na current density in $\mathrm{PC1} 2$ cells that occurs in response to EGF can be accounted for by the relatively modest increase in type II Na channel mRNA expression.

In contrast to the effects of EGF and NGF, exposure to insulin for $7 \mathrm{~d}$ did not appear to increase $\mathrm{Na}$ channel expression in $\mathrm{PC} 12$ cells. In wild-type cells, insulin did not increase the proportion of cells with appreciable Na currents $(6 / 13)$ when compared to untreated cells $(9 / 20)$, nor did it cause increases in cell size, $\mathrm{Na}$ current magnitude, or $\mathrm{Na}$ current density (Fig. 7A). This was not unique to the culture medium or type of serum used, as insulin was also ineffective in increasing $\mathrm{Na}$ channel expression in a subline of PC12 cells maintained under slightly different culture conditions (see Fig. 10).

In addition to differences in the specific tyrosine kinase receptors with which NGF and EGF interact, NGF, but not EGF, can also interact with a $75 \mathrm{kDa}$ transmembrane glycoprotein (p75) that is expressed in PC12 cells and many subpopulations of neurons (Johnson et al., 1986; Buck et al., 1987; Radeke et al., 1987). Although the role of p75 in NGF function is not clearly defined (for discussion, see Chao, 1992a; Meakin and Shooter, 1992), we made an initial investigation into the impact of this difference on $\mathrm{Na}$ channel regulation by analyzing a subline of PC12 cells (EN30B) expressing chimeric receptors consisting of the ligand binding domain of the EGF receptor and the transmembrane and cytoplasmic domains of the p75 receptor (Yan et al., 1991). In these cells, the response to EGF more closely resembles the response to $\mathrm{NGF}$, including increases in neurite outgrowth and transin gene expression (Yan et al., 1991). In our experiments, the cells responded as expected, with neurite outgrowth observed in response to EGF as well as NGF (data not shown). In addition, when treated with NGF for $7 \mathrm{~d}$, the proportion of EN $30 \mathrm{~B}$ cells with appreciable Na currents $(>50 \mathrm{pA})$ increased (from 10/21 to 26/26) and there was a significant ( $p$ $<0.01)$ increase in the average magnitude of the Na currents and average $\mathrm{Na}$ current density (Fig. $7 \mathrm{~A}$ ). In contrast, when treated with EGF for $7 \mathrm{~d}$ the average $\mathrm{Na}$ current density in the EN30B cells was very similar to that in wild-type PC12 cells treated with EGF, and the density relative to untreated and NGF-treated EN30B cells was similar to the relative increases observed in wild-type PC12 cells (Fig. 7A). Furthermore, when $\mathrm{Na}$ channel mRNA expression was analyzed using Northern blot analysis, the increase in Na channel mRNA in EN30B cells treated with EGF (1.8-fold) was similar to that in wild-type PC1 2 cells treated with EGF (1.7-fold), rather than comparable to the NGF-mediated increases in EN30B (4.5-fold) and wildtype cells (4.1-fold) (Fig. $7 B$ ). Therefore, coexpression of the chimeric receptor did not elevate the level of $\mathrm{Na}$ channel expression induced by EGF to the level induced by NGF, and suggests that the difference in the ability of NGF and EGF to interact with $\mathrm{p} 75$ does not account for the difference in the ability of these two factors to induce $\mathrm{Na}$ channel expression. 
A

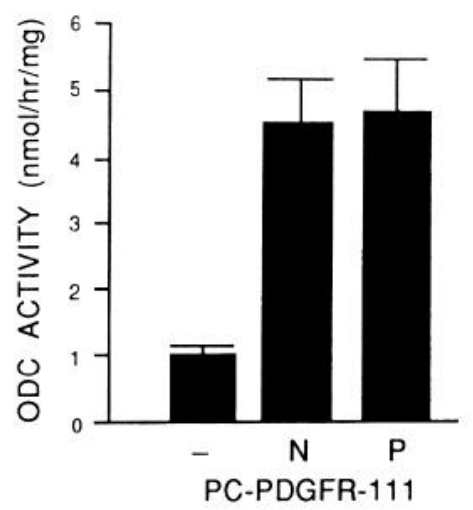

C
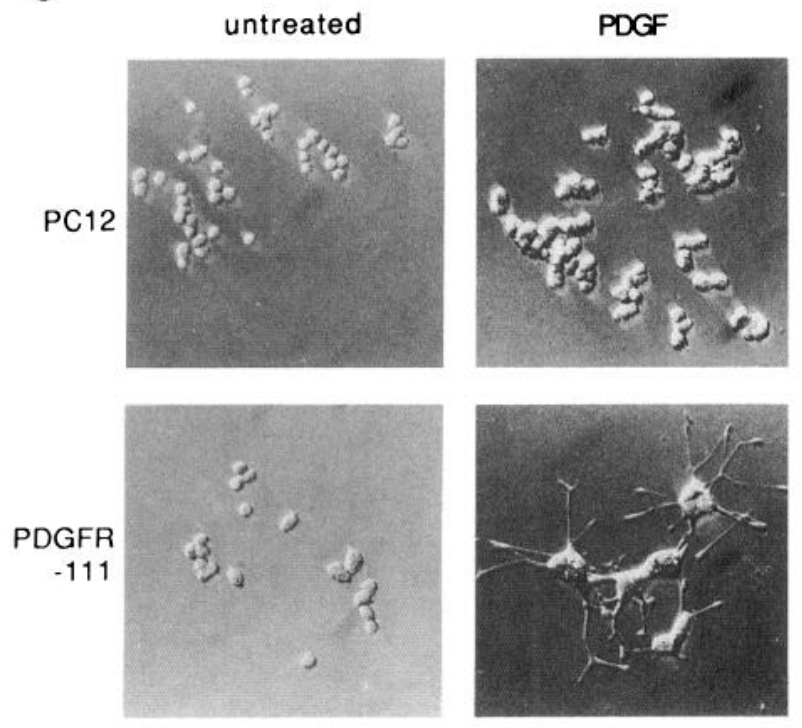

PC-PDGFR-111

P N

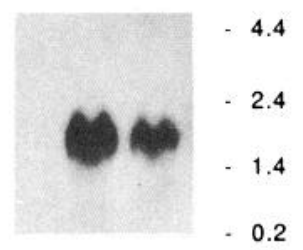

0.2
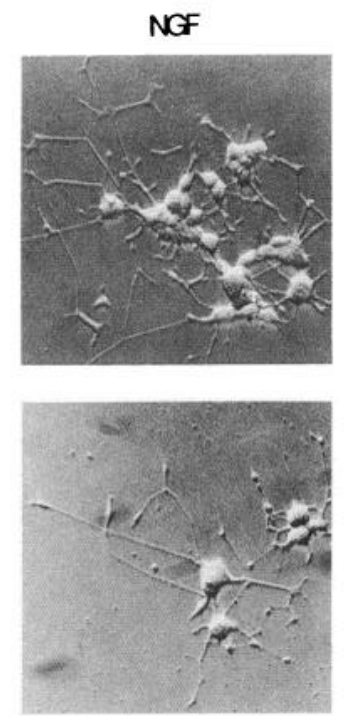

Figure 8. Responsiveness of $\mathrm{PC1} 2$ cells stably expressing PDGF receptors to PDGF and NGF treatment. $A$, Ornithine decarboxylase $(O D C)$ activity in PC-PDGFR-111 cells either untreated (-), treated with $100 \mathrm{ng} / \mathrm{ml} \mathrm{NGF}$ $(N)$, or treated with $30 \mathrm{ng} / \mathrm{ml}$ PDGF $(P)$ for $5 \mathrm{hr}$. $B$, Northern blot analysis of c-fos mRNA expression in PC-PDGFR111 cells either untreated $(-)$ or treated for 30 min with $30 \mathrm{ng} / \mathrm{ml}$ PDGF $(P)$ or $100 \mathrm{ng} / \mathrm{ml} \mathrm{NGF}(N)$. The position and the molecular sizes $(\mathrm{kb})$ of a commercially available RNA ladder (Bethesda Research Labs) are shown on the right. $C$, Photographs of PC-NEO-102 (PC12) and PC-PDGFR-111 cells either untreated or treated for $7 \mathrm{~d}$ with $30 \mathrm{ng} /$ $\mathrm{ml}$ PDGF or $100 \mathrm{ng} / \mathrm{ml}$ NGF. The photographs show that while both sublines of $\mathrm{PC} 12$ cells extend neurites in response to NGF, only the PC-PDGFR111 subline does so in response to PDGF. Cell bodies in the untreated PC1 2 cells are approximately $15 \mu \mathrm{m}$ in diameter.

PDGF can regulate type II Na channel expression in PC12 cells expressing $\beta-P D G F$ receptors

There is evidence to suggest that PDGF has a neurotrophic role during development of the nervous system (Smits et al., 1991). Although wild-type $\mathrm{PC} 12$ cells do not express PDGF receptors, if $\beta$-PDGF receptors are stably expressed in PC12 cells, the PDGF-mediated cessation of cell division, persistent MAP kinase activation, and neurite outgrowth are similar to that observed in the cells in response to NGF (Heasley and Johnson, 1992). In order to determine whether this apparent neuronal differentiation in response to PDGF includes an increase in $\mathrm{Na}$ channel expression, we analyzed two different $\mathrm{PC} 12$ sublines that stably express a cDNA encoding full length $\beta$-PDGF receptors (PC-PDGFR-102 and PC-PDGFR-111), as well as a subline of the parental PC12 cells stably transfected with an expression vector lacking PDGF receptor cDNA that simply confers neomycin resistance (PC-NEO-102). Analysis of this latter subline served as a control for the effects of transfection, the exposure to the antibiotic neomycin, and the effects of PDGF on wild-type cells. Indication that the PC-PDGFR-102 and PCPDGFR-111 cells responded to our PDGF treatment included PDGF-mediated increases in ODC activity and c-fos mRNA that were comparable to that induced by NGF (Fig. $8 A, B$ ). In

addition to these new findings, we also found that PDGF elicited neurite outgrowth in these cells comparable to that elicited by NGF (Fig. 8C), consistent with previous observations (Heasley and Johnson, 1992), and in contrast to the total lack of effect of PDGF on the PC-NEO-102 cells (Fig. $8 C$ ).

To determine if there was a change in type II Na channel gene expression in the PC-PDGFR-111 and PC-PDGFR-102 cells in response to PDGF, RNA samples from these cells were analyzed in RNase protection assays using a probe specific for type II Na channel mRNA (Fig. 9). In control experiments with PCNEO-102 cells, exposure to NGF, but not PDGF, for $7 \mathrm{~d}$ increased the levels of type II Na channel mRNA (Fig. 9). In the PC-PDGFR-111 cells, exposure to PDGF for $7 \mathrm{~d}$ caused an increase in type II Na channel mRNA (Fig. 9) that was comparable to the response to NGF (5.4-fold vs 4.7-fold). Similar increases in type II Na channel mRNA were also detected when the PC-PDGFR-102 subline was treated with PDGF or NGF (data not shown).

To determine if the changes in $\mathrm{Na}$ channel gene expression in the PC-PDGFR-111 and PC-PDGFR-102 cells were accompanied by changes in functional $\mathrm{Na}$ channel expression, wholecell patch-clamp recordings were used to compare the effects of NGF and PDGF on the expression of functional Na channels in the PC-PDGFR-102, PC-PDGFR-111, and PC-NEO-102 


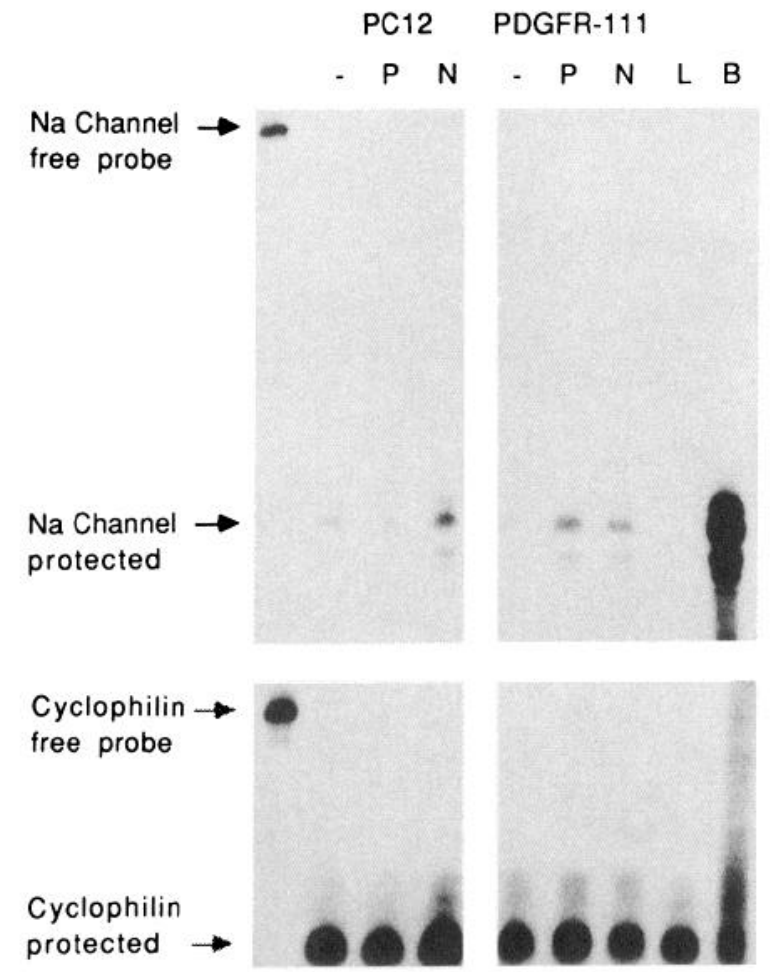

Figure 9. RNase protection analysis of the growth factor-mediated induction of type II Na channel mRNA in neomycin-resistant PC12 cells and PC12 cells stably expressing PDGF receptors. PC-NEO-102 cells $(P C 12)$ and the PC-PDGFR-111 subline of PC12 cells (PDGFR$11 I$ ) were either untreated $(-)$ or treated for $7 \mathrm{~d}$ with $30 \mathrm{ng} / \mathrm{ml}$ PDGF $(P)$ or $100 \mathrm{ng} / \mathrm{ml} \mathrm{NGF}(N)$. RNA samples from these cells, as well as RNA from rat liver $(L)$ and rat brain $(B)$, were analyzed using a 219 bp probe specific for type II Na channel mRNA, which protects a 128 bp fragment, and a 62 bp probe specific for cyclophilin mRNA, which protects a 37 bp fragment (see Fanger et al., 1993).

cells. As expected for the PC-NEO-102 control subline of cells, exposure to PDGF for $7 \mathrm{~d}$ had no effect on Na channel expression in these cells (Fig. 10A,C), while treatment with NGF for $7 \mathrm{~d}$ caused the proportion of cells with appreciable $\mathrm{Na}$ currents ( $>50 \mathrm{pA}$ ) to increase (from $2 / 10$ to $9 / 10$ ) and caused a significant $(p<0.01)$ increase in the magnitude of the $\mathrm{Na}$ currents and the average Na current density (Fig. $10 \mathrm{~A}, \mathrm{C}$ ). In contrast, PDGF caused dramatic increases in $\mathrm{Na}$ channel expression in both the PC-PDGFR-111 and PC-PDGFR-102 cells. The proportion of PDGF-treated PC-PDGFR-111 and PC-PDGFR-102 cells with appreciable Na currents $(23 / 25,22 / 22)$ was similar to that observed in response to NGF treatment $(22 / 22,22 / 22)$, and the increases in the magnitude of the $\mathrm{Na}$ currents, average cell size, and average $\mathrm{Na}$ current density were not only significant $(p<$ 0.01 ), but were also comparable to those elicited in the cells by NGF (Fig. 10B,C). The effects of PDGF were significantly ( $p$ $<0.01)$ greater than the effects of EGF or insulin on these cells, and the increased $\mathrm{Na}$ channel expression in PDGF-treated cells was evident when different types of serum were used in the culture medium (Fig. 10C). The five- to sixfold inductions in $\mathrm{Na}$ current density in response to PDGF were similar in magnitude to the PDGF-mediated induction of type II Na channel mRNA in these cells, and provided further indication that activation of PDGF receptors in these cells can induce $\mathrm{Na}$ channel expression.
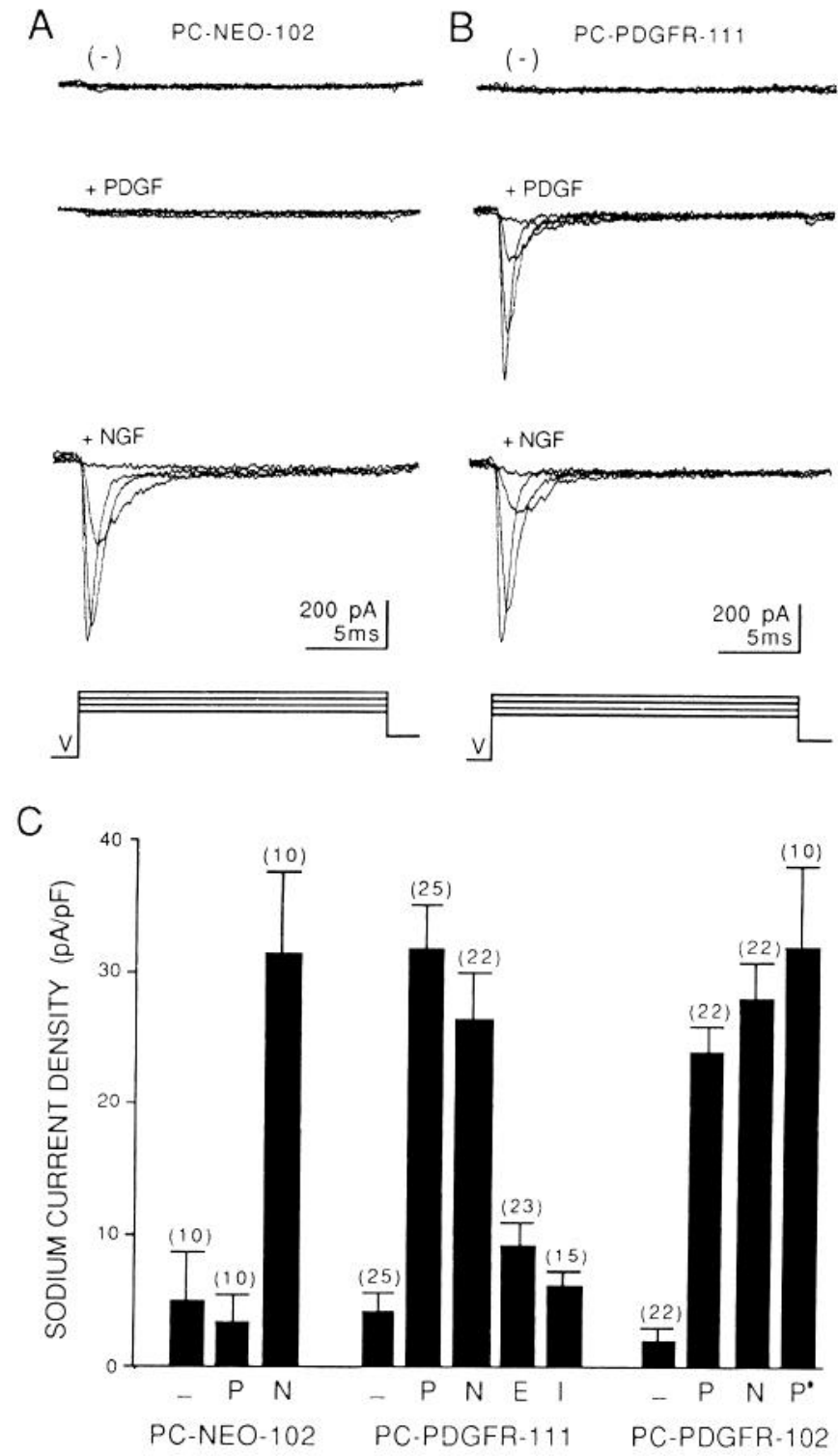

Figure 10. Na current density in $\mathrm{PC1} 2$ cells stably expressing PDGF receptors. Representative recordings of voltage-dependent $\mathrm{Na}$ currents in $\mathrm{PC} 12$ cells stably expressing a gene conferring neomycin resistance $(A, P C-N E O-102)$ and $\mathrm{PC} 12$ sublines stably expressing PDGF receptors $(B, P C-P D G F R-111)$. Cells were either untreated $(-)$ or treated for 7 d with $30 \mathrm{ng} / \mathrm{ml}$ PDGF or $100 \mathrm{ng} / \mathrm{ml}$ NGF. Superimposed current records illustrate the response to depolarizing pulses to $-40,-30,-20$, and $-10 \mathrm{mV}$, from a prepulse potential of $-120 \mathrm{mV}$ and holding potential of $-80 \mathrm{mV}$. C, Average Na current density in PC-NEO-102, PC-PDGFR-111, and PC-PDGFR-102 cells that were either untreated $(-)$ or treated for $7 \mathrm{~d}$ with $30 \mathrm{ng} / \mathrm{ml}$ PDGF $(P), 100 \mathrm{ng} / \mathrm{ml} \mathrm{NGF}(N)$, $100 \mathrm{ng} / \mathrm{ml} \mathrm{EGF}(E), 300 \mathrm{nM}$ insulin $(I)$, or $30 \mathrm{ng} / \mathrm{ml}$ PDGF in culture medium containing the serum routinely used to culture PC12 cells, rather than the plasma-derived, relatively PDGF-free serum $\left(P^{*}\right)$. The number of cells in each group is in parentheses above the bars. Error bars represent the SEM. Cell membrane capacitance (mean \pm SEM) was $5.8 \pm 0.2 \mathrm{pF}$ for untreated, $5.3 \pm 0.2 \mathrm{pF}$ for PDGF-treated, and $10.9 \pm 0.9 \mathrm{pF}$ for NGF-treated PC-NEO-102 cells, $9.1 \pm 0.5 \mathrm{pF}$ for untreated, $20.5 \pm 1.8 \mathrm{pF}$ for PDGF-treated, $18.4 \pm 0.8 \mathrm{pF}$ for NGFtreated, $10.0 \pm 0.5 \mathrm{pF}$ for EGF-treated, and $10.5 \pm 0.5 \mathrm{pF}$ for insulintreated PC-PDGFR-111 cells, $8.4 \pm 0.5 \mathrm{pF}$ for untreated, $23.6 \pm 2.8$ $\mathrm{pF}$ for PDGF-treated, $18.2 \pm 1.4 \mathrm{pF}$ for NGF-treated, and $21.8 \pm 2.8$ $\mathrm{pF}$ for PDGF-treated (normal serum) PC-PDGFR-102 cells. 


\section{Discussion}

There is considerable interest in the actions of growth factors and their receptors, from understanding the signal transduction mechanisms they utilize, to defining the cellular responses they govern and biological roles they play in nervous system development. However, in previous studies investigating the abilities of these receptors to elicit neuronal differentiation, the number of neuronal-specific responses examined has been small, and often limited to responses dependent on growth factor-induced ras activity. Therefore, to further delineate the capabilities of various receptor tyrosine kinases (RTKs) to induce neuronal differentiation, we have determined their ability to induce $\mathrm{Na}$ channel expression in PC12 cells. We demonstrate for the first time that activation of either trkB or trkC is capable of inducing type II Na channel mRNA expression in PC12 cells. The results further define the signaling capabilities of these receptors by showing that in addition to eliciting changes that are ras-dependent, such as neurite outgrowth, they can elicit neuronalspecific responses, like $\mathrm{Na}$ channel induction, that have been shown to be ras-independent (D'Arcangelo and Haleguoa, 1993; Fanger et al., 1993). We have also analyzed the effect of trkA overexpression on the NGF-mediated induction of $\mathrm{Na}$ channel expression. When compared to the various responses to NGF that were monitored in the initial characterization of the trkAoverexpressing cells (Hempstead et al., 1992), expression of type II $\mathrm{Na}$ channel mRNA appears to be most similar to that of peripherin mRNA, where the induction by NGF was not noticeably enhanced, yet the basal level of expression was slightly elevated. This is in sharp contrast to the augmented induction of transin mRNA. As previously suggested (Hempstead et al., 1992), the relative insensitivity of some late responses and not others may reside in differences in the regulatory mechanisms involved, consistent with the ras-dependent induction of transin and ras-independent regulation of Na channel expression (D'Arcangelo and Haleguoa, 1993; Fanger et al., 1993).

We also show for the first time that PDGF receptor activation in PC1 2 cells can induce type II Na channel mRNA and functional Na channel expression, as well as ODC activity and c-fos mRNA. Induction of $\mathrm{Na}$ channel expression is the first example of a neuronal-specific gene being induced by PDGF, and when combined with previous results (Heasley and Johnson, 1992) extends the list of responses that can be elicited in PC12 cells by PDGF receptor activation to include increases in ODC activity, c-fos mRNA, MAP kinase activity, neurite outgrowth, and $\mathrm{Na}$ channel expression. Thus, as previously suggested (Sasahara et al., 1991; Smits et al., 1991; Eccleston et al., 1993), PDGF may have a more expanded role in the nervous system. than previously imagined, with effects not only on glial cells (for review, see Richardson et al., 1990), but on neuronal components of the nervous system as well.

The disparate biological effects of NGF, EGF, and insulin on $\mathrm{PC} 12$ cells have led to considerable analysis of the biochemical changes they elicit in an effort to identify mechanisms important to neuronal differentiation (for discussion, see Saltiel and Decker, 1991; Chan, 1992h). Here we demonstrate for the first time that while insulin is unable to induce $\mathrm{Na}$ channel expression in PC1 2 cells, EGF elicits a modest increase in Na channel mRNA that, like the response to NGF, appears to be due largely to an increase in the level of type II Na channel mRNA. This contrasts to the much larger increase in type II Na channel mRNA caused by NGF, which occurs with a time course similar to the NGF- mediated increases in peripherin and neurofilament- $\mathrm{L}$ mRAs (Lindenbaum et al., 1988; Hempstead et al., 1992). This pattern of responses resembles the regulation of GAP-43 expression in PC12 cells, where insulin is ineffective and there is a muted response to EGF in comparison to NGF (Costello et al., 1990). Given the responses were compared in the same neuronal cellular environment, it suggests that mechanisms related to the receptors themselves, rather than cell-specific differences in cellular components, play an important role in determining the response.

Among the features that could account for the differential regulation of $\mathrm{Na}$ channel expression by various growth factors are differences in their receptors. For example, evidence suggests that in addition to the trk RTKs, p75 plays a biological role in the response to neurotrophins (Lee et al., 1992; Davies et al., 1993), though its exact role and participation in signal transduction are controversial (for discussion, see Chao, 1992a). However, with regard to $\mathrm{Na}$ channel expression in PC1 2 cells, there are several indications that ligand interactions with $\mathrm{p} 75$ probably do not play a role in the growth factor-mediated specificity. First, growth factors that interact with $\mathrm{p} 75$, such as NGF and BDNF, as well as those that do not, including bFGF and PDGF, can induce Na channel expression (Pollock et al., 1990; Ginty et al., 1992; present study). Second, as we show here, expression of an EGF receptor/p75 receptor chimera in $\mathrm{PC} 12$ cells does not increase the extent to which EGF induces $\mathrm{Na}$ channel expression. Finally, a mutant form of NGF that predominantly associates with trkA and not $\mathrm{p} 75$ appears sufficient for Na channel induction in PCl 2 cells (G. Fanger, P. Barker, E. Shooter, and R. Maue, unpublished observations). Upon examination of the RTKs, it is also clcar that scquence similarity alone is not indicative of the ability to regulate $\mathrm{Na}$ channel expression. For example, based on sequence, the insulin receptor is more homologous to the trk RTKs than the PDGF receptor is (for discussion, see Saltiel and Decker, 1991), yet in PC12 cells PDGF receptor activation can induce many of the same changes as trk receptor activation, while activation of the insulin receptor is ineffective. As a result, although perhaps not surprising, it is of interest to discover that trkB and trkC can induce $\mathrm{Na}$ expression in $\mathrm{PC} 12$ cells similar to trkA. Identifying receptors with similar capabilities allows common structural features to be identified and analyzed as to their effect on $\mathrm{Na}$ channel induction. For example, the large carboxy-terminal tails of the EGF and insulin receptors, which have been implicated in negative regulation of receptor autophosphorylation (for discussion, see Saltiel and Decker, 1991), may suppress sustained signaling necessary for $\mathrm{Na}$ channel expression, and could serve as a focus for further analysis.

Differences in growth factor receptors may result in overlapping, yet distinct subsets of signaling mechanisms utilized by individual growth factors (for discussion, see Schlessinger and Ullrich, 1992). Many signaling pathways and intermediates have been implicated in mediating the actions of growth factors, including phospholipid turnover, cAMP, arachidonic acid, and a variety of protein kinases (for review, see Haleguoa et al., 1991). In many cases, signaling components are either coupled to activated receptors through direct interaction, as in the case of phospholipase $\mathrm{C}_{\gamma}$ and phosphotidylinositol-3-kinase, or indirectly through adapter or linking proteins, as in the case of the ras-associated cascade of protein kinases (for reviews, see Schlessinger and Ullrich, 1992; McCormick, 1993). These rapid changes trigger gene expression, through modification and ac- 
tivation of preexisting transcription factors (Fu and Zhang, 1993; Silvennoinen et al., 1993) and activation of genes encoding proteins such as c-fos, c-jun, and jun-B (Bartel et al., 1989), which in turn serve as transcription factors (Gizang-Ginsberg and Ziff, 1990; for review, see Haleguoa et al., 1991). Among these changes, receptors that can induce $\mathrm{Na}$ channel expression in PC12 cells, including those for NGF, bFGF, and PDGF, cause persistent activation of MAP kinase, whereas receptors for insulin and EGF do not (Heasley and Johnson, 1992; Ohmichi et al., 1993). Furthermore, receptors that can induce $\mathrm{Na}$ channcl cxpression can also cause rapid tyrosine phosphorylation of a nuclear protein (SNT), while EGF receptor activation is ineffective (Rabin et al., 1993). For Na channel regulation, the significance of specific signaling components such as these remains to be determined.

In the present study we have shown there are both intrinsic similarities and differences in the ability of growth factors and their RTKs to regulate neuronal $\mathrm{Na}$ channel expression. The results suggest that for a number of growth factors there may be important, yet currently unappreciated, roles in regulating $\mathrm{Na}$ channel expression during nervous system development and regeneration. With identification of an increasing number of growth factors and receptors within the nervous system (Berkemeier et al., 1991; Ip et al., 1992; Tsoulfas et al., 1993; Valenzuela et al., 1993; for review, see Chao, 1992a), determining the ability of these newly identified molecules to influence $\mathrm{Na}$ channel expression will be important for dissecting their cellular modes of action. Furthermore, analysis and comparison of RTKs, including those with alterations in their cytoplasmic domains because of alternative splicing (Klein et al., 1990; Middlemas et al., 1991; Tsoulfas et al., 1993; Valenzuela et al., 1993) or experimentally induced mutations (Kazlauskas and Cooper, 1989; Decker, 1993; Stephens et al., 1994), should allow selective elimination or activation of specific signaling pathways and identification of mechanisms important for $\mathrm{Na}$ channel expression and neuronal differentiation.

\section{References}

Auld VJ, Goldin AL, Krafte DS, Marshall J, Dunn JM, Catterall WA Lester HA, Davidson N, Dunn RJ (1988) A rat brain Na channel alpha subunit with novel gating properties. Neuron 1:449-461.

Barde YA (1989) Trophic factors and neuronal survival. Neuron 2:1525-1534.

Bartel DP, Sheng M, Lau LF, Greenberg ME (1989) Growth factors and membrane depolarization activate distinct programs of early response gene expression: dissociation of fos and jun induction. Genes Dev 3:304-313.

Beckh S, Noda M, Lubbert H, Numa S (1989) Differential regulation of three messenger RNAs in the rat central nervous system during development. EMBO J 8:3611-3616.

Berkemeier LR, Winslow JW, Kaplan DR, Nikolics K, Goeddel DV, Rosenthal A (1991) Neurotrophin-5: a novel neurotrophic factor that activates trk and trkB. Neuron 7:857-866.

Bhat NR (1983) Insulin dependent neurite outgrowth in cultured embryonic mouse brain cells. Brain Res 313:315-318.

Borasio GD, Markus A, Wittinghofer A, Barde Y-A, Heumann R (1993) Involvement of ras p2 1 in neurotrophin-induced response of sensory, but not sympathetic neurons. J Cell Biol 121:665-672.

Bothwell M (1991) Tissue localization of nerve growth factor and nerve growth factor receptor. In: Current topics in microbiology and immunology, Vol 165 (Bothwell M, ed), pp 55-70. Berlin: Springer.

Buck CR, Martinez H, Black IB, Chao MV (1987) Developmentally regulated expression of the nerve growth factor receptor gene in the periphery and the brain. Proc Natl Acad Sci USA 84:3060-3063.

Chao MV (1992a) Neurotrophin receptors: a window into neuronal differentiation. Neuron 9:583-593.
Chao MV (1992b) Growth factor signaling: where is the specificity? Cell 68:995-997.

Chirgwin JM, Przybyla AE, MacDonald RJ, Rutter WJ (1979) Isolation of biologically active ribonucleic acids from sources enriched in ribonuclease. Biochemistry 18:5294-5299.

Cooperman SS, Grubman SA, Barch RL, Goodman RH, Mandel G (1987) Modulation of sodium channel mRNA levels in rat skeletal muscle. Proc Natl Acad Sci USA 84:8721-8725.

Costello B, Meymandi A, Freeman JA (1990) Factors influencing GAP-43 gene expression in PC12 pheochromocytoma cells. J Neurosci 10:1398-1406.

D'Arcangelo G, Haleguoa S (1993) A branched signaling pathway for nerve growth factor is revealed by src-, ras-, and raf-mediated gene inductions. Mol Cell Biol 13:3146-3155.

Davies AM, Lee K-F, Jaenisch R (1993) p75-deficient trigeminal sensory neurons have an altered response to NGF but not to other neurotrophins. Neuron 11:565-574.

Decker SJ (1993) Transmembrane signaling by epidermal growth factor receptors lacking autophosphorylation sites. J Biol Chem 268: 9176-9179.

Dichter MA, Tischler AS, Greene LA (1977) Nerve growth factorinduced increase in electrical excitability and acetylcholine sensitivity of a rat pheochromocytoma cell line. Nature 268:501-504.

Djurhuus R (1981) Ornithine decarboxylase (EC 4.1.1.17) assay based upon the retention of putrescine by a strong cation exchange paper. Anal Biochem 113:352-355.

Eccleston PA, Funa K, Heldin CH (1993) Expression of platelet-derived growth factor (PDGF) and PDGF $\alpha$ - and $\beta$-receptors in the peripheral nervous system: an analysis of sciatic nerve and dorsal root ganglia. Dev Biol 155:459-470.

Fanger GR, Erhardt P. Cooper GM, Maue RA (1993) Ras-independent induction of rat brain type II sodium channel expression in nerve growth factor-treated PCI2 cells. J Neurochem 61:1977-1980.

Fu X, Zhang J (1993) Transcription factor p91 interacts with the epidermal growth factor receptor and mediates activation of the c-fos promoter. Cell 74:1135-1145.

Gage FH, Tuszynski MH, Chen KS, Fagan AM, Higgins GA (1991) Nerve growth factor function in the central nervous system. In: Current topics in microbiology and immunology, Vol 165 (Bothwell M, ed), pp 71-93. Berlin: Springer.

Ginty DD, Fanger GR, Wagner JA, Maue RA (1992) The activity of cAMP-dependent protein kinase is required at a posttranslational level for the induction of voltage-dependent sodium channels by peptide growth factors in PCI2 cells. J Cell Biol 116:1465-1473.

Gizang-Ginsberg E, Ziff EB (1990) Nerve growth factor regulates tyrosine hydroxylase gene transcription through a nucleoprotein complex that contains c-Fos. Genes Dev 4:477-491.

Greene LA, Tischler AS (1982) PC12 pheochromocytoma cells in neurobiology research. Adv Cell Neurobiol 3:373-414.

Halegoua S, Armstrong RC, Kremer NE (1991) Dissecting the mode of action of a neuronal growth factor. In: Current topics in microbiology and immunology, Vol 165 (Bothwell M, ed), pp 95-118. Berlin: Springer.

Heasley LE, Johnson GL (1992) The $\beta$-PDGF receptor induces ncuronal differentiation of PC12 cells. Mol Biol Cell 3:545-553.

Hempstead BL, Rabin SJ, Kaplan L, Reid S, Parada LF, Kaplan DR (1992) Overexpression of the trk tyrosine kinase receptor rapidly accelerates nerve growth factor-induced differentiation. Neuron 9:883896.

Hod Y (1992) A simplified ribonuclease protection assay. Biotechniques 13:852-854.

Hodgkin AL, Huxley AF (1952) A quantitative description of membrane current and its application to conduction and excitation in nerve. J Physiol (Lond) 117:500-544.

Hohn A, Leibrock J, Bailey K, Barde Y (1990) Identification and characterization of a novel member of the nerve growth factor/brain derived neurotrophic factor family. Nature 344:339-341.

Huff K, End D, Guroff G (1981) Nerve growth factor-induced alteration in the response of $\mathrm{PC} 12$ pheochromocytoma cells to epidermal growth factor. J Cell Biol 88:189-198.

Ip NY, Ibanez CF, Nye SH, McClain J, Jones PF, Gies DR, Belluscio L, LeBeau MM, Espinosa R, Squinto SP, Persson H, Yancopoulos GD (1992) Mammalian neurotrophin-4: structure, chromosomal localization, tissue distribution, and receptor specificity. Proc Natl Acad Sci USA 89:3060-3064. 
Ip NY, Stitt TN, Tapley P, Klein R, Glass DJ, Fandl J, Greene LA, Barbacid M, Yancopoulos GD (1993) Similarities and differences in the way neurotrophins interact with the trk receptors in neuronal and nonneuronal cells. Neuron 10:137-149.

Johnson D, Lanaham A, Buck CR, Seghal A, Morgan C, Mercer E, Bothwell M, Chao M (1986) Expression and structure of the human NGF receptor. Cell 47:545-554.

Kazlauskas A, Cooper JA (1989) Autophosphorylation of the PDGF receptor in the kinase insert region regulates interactions with cell proteins. Cell 58:1121-1133.

Klein R, Parada LF, Coulier F, Barbacid M (1989) trkB, a novel tyrosine protein kinase receptor expressed during mouse neural development. EMBO J 8:3701-3709.

Klein R, Conway D, Parada LF, Barbacid M (1990) The trkB tyrosine kinase gene codes for a second neurogenic receptor that lacks the tyrosine kinase domain. Cell 61:647-656.

Lamballe F, Klein R, Barbacid M (1991) trkC, a new member of the trk family of tyrosine protein kinases, is a receptor for neurotrophin3. Cell 66:967-979.

Lee KF, Li E, Huber LJ, Landis SC, Sharpe AH, Chao MV, Jaenisch $R$ (19.92) Targeted mutation of the gene encoding the low affinity NGF receptor p75 leads to deficits in the peripheral sensory nervous system. Cell 69:737-749.

Levi-Montalcini R (1987) The ncrve growth factor: thirty-five years later. EMBO J 6:1145-1154.

Liebrock J, Lottspeich F, Hohn A, Hofer M, Hengerer B, Maisakowski $P$, Thoenen $H$, Barde $Y$ (1989) Molecular cloning and expression of brain derived neurotrophic factor. Nature 341:149-152.

Lindenbaum MH, Carbonetto S, Grosveld F, Flavell D, Mushynski WE (1988) Transcriptional and post-transcriptional effects of nerve growth factor on expression of the neurofilament subunits in PC-12 cells. J Biol Chem 263:5662-5667.

Machida CM, Rodland KD, Matrisian L, Magun BE, Ciment G (1989) NGF induction of the gene encoding the protease transin accompanies neuronal differentiation. Neuron 2:1587-1596.

Maisonpierre PC, Belluscio L, Squinto L, Ip NY, Furth ME, Lindsay RM, Yancopoulos GD (1990) Neurotrophin-3: a neurotrophic factor related to NGF and BDNF. Science 247:1446-1451.

Mandel G (1992) Tissue-specific expression of the voltage-sensitive sodium channel. J Membr Biol 125:193-205.

Mandel G, Cooperman SS, Maue RA, Goodman RH, Brehm P (1988) Selective induction of brain type II Na channels by nerve growth factor. Proc Natl Acad Sci USA 85:924-928.

Maue RA, Kraner SD, Goodman RH, Mandel G (1990) Neuronspecific expression of the rat brain type II sodium channel gene is directed by upstream regulatory elements. Neuron 4:223-231

McCormick F (1993) How receptors turn ras on. Nature 363:15-16.

Meakin SO, Shooter EM (1992) The nerve growth factor family of receptors. Trends Neurosci 15:323-331.

Middlemas DS, Lindberg RA, Hunter T (1991) trkB, a neural receptor protein-tyrosine kinase: evidence for a full length and two truncated receptors. Mol Cell Biol 11:143-153.

Noda M, Ikeda T, Suzuki H, Takeshima H, Takahashi T, Kuno M, Numa S (1986) Existence of distinct sodium channel messenger RNAs in rat brain. Nature 320:188-192.

Ohmichi M, Pang L, Ribon V, Saltiel AR (1993) Divergence of signaling pathways for insulin in PC-12 pheochromocytoma cells. Endocrinology 133:46-56.

Pollock JD, Krempin M, Rudy B (1990) Differential effects of NGF, FGF, EGF, cAMP, and dexamethasone on neurite outgrowth and sodium channel expression in PC12 cells. J Neurosci 10:2626-2637.

Qiu M, Green SH (1992) PC12 cell neuronal differentiation is associated with prolonged p2 1 ras activity and consequent prolonged ERK activity. Neuron 9:705-717.

Rabin SJ, Cleghon V, Kaplan DR (1993) SNT, a differentiation-spe- cific target of neurotrophic factor-induced tyrosine kinase activity in neurons and PCI2 cells. Mol Cell Biol 13:2203-2213.

Radeke MJ, Misko TP, Hsu C, Herzenberg LA, Shooter EM (1987) Gene transfer and molecular cloning of the rat nerve growth factor receptor. Nature 325:593-597.

Recio-Pinto E, Rechler MM, Ishii DN (1986) Effects of insulin, insulin-like growth factor II, and nerve growth factor on neurite formation and survival in cultured sympathetic and sensory neurons $J$ Neurosci 6:1211-1219.

Richardson WD, Raff M, Noble M (1990) The oligodendrocyte-type 2 astrocyte lineage. Semin Neurosci 2:445-454.

Saltiel R, Decker SJ (1991) Diversity in cellular signaling for nerve growth factor and insulin: variations on a common theme. Mol Cell Endocrinol 81:197-202.

Sasahara M, Fries JWU, Raines EW, Gown AM, Westrum LE, Frosch MP, Bonthron DT, Ross R, Collins ' $T$ (1991) PDGF $\beta$-chain in neurons of the central nervous system, posterior pituitary, and in a transgenic model. Cell 64:217-227.

Scheinman RI, Auld VJ, Goldin AL, Davidson N, Dunn RJ, Catterall WA (1989) Developmental regulation of sodium channel expression in the rat forebrain. J Biol Chem 264:10660-10666.

Schlessinger J, Ullrich A (1992) Growth factor signaling by receptor tyrosine kinases. Neuron 9:383-391.

Sills MN, Xu YC, Barachini E, Goodman RH, Cooperman SS, Mandel $\mathrm{G}$, Chien KR (1989) Expression of diverse $\mathrm{Na}$ channel messenger RNAs in rat myocardium. J Clin Invest 84:331-336.

Silvennoinen O, Schindler C, Schlessinger J, Levy DE (1993) rasindependent growth factor signaling by transcription factor tyrosine phosphorylation. Science 261:1736-1739.

Smits A, Kato M, Westermark B, Nister M, Heldin CH, Funa K (1991) Neurotrophic activity of platelet-derived growth factor (PDGF): rat neuronal cells possess functional PDGF $\beta$-type receptors and respond to PDGF. Proc Natl Acad Sci USA 88:8159-8163.

Stephens RM, Loeb DM; Copeland TD, Pawson T, Greene LA, Kaplan DR (1994) Trk receptors use redundant signal transduction pathways involving SHC and PLC- $\gamma 1$ to mediate NGF responses. Neuron 12:691-705

Suzuki HS, Beckh S, Kubo H, Yahagi N, Ishida H, Kayano T, Noda M, Numa S (1988) Functional expression of cloned cDNA encoding sodium channel III. FEBS Lett 228:195-200.

Thoenen $\mathrm{H}$ (1991) The changing scene of neurotrophic factors. Trends Neurosci 14:165-170.

Tsoulfas P, Soppet D, Escandon E, Tessarollo L, Mendoza-Ramirez JL, Kosenthal A, Nikolics K, Parada LF (1993) The rat trkC locus encodes multiple neurogenic receptors that exhibit differential response to neurotrophin-3 in PC12 cells. Neuron 10:975-990.

Valenzuela DM, Maisonpierre PC, Glass DJ, Rojas E, Nunez L, Kong Y, Gies DR, Stitt TN, Ip NY, Yancopoulos GD (1993) Alternative forms of rat trkC with different functional capabilities. Neuron 10: 963-974.

Wagner JA, Kostyk SK (1991) Regulation of neural survival and differentiation by peptide growth factors. Curr Opin Cell Biol 2:1050 1057.

Walicke P, Baird A (1988) Neurotrophic effects of basic and acidic fibroblast growth factors are not mediated through glial cells. Brain Res 468:71-79.

Wollner DA, Scheinmann R, Catterall WA (1988) Sodium channel expression and assembly during development of retinal ganglion cells. Neuron 1:727-737.

Yan H, Schlessinger J, Chao MV (1991) Chimeric NGF-EGF receptors define domains responsible for neuronal differentiation. Science 252: 561-563.

Yeh HJ, Ruit KG, Wang YX, Parks WC, Snider WD, Deuel TF (1991) PDGF $\alpha$-chain gene is expressed by mammalian neurons during development and in maturity. Cell 64:209-216. 